\title{
Structural Characterization of Guaiacyl-rich Lignins in Flax (Linum usitatissimum) Fibers and Shives
}

\author{
José C. del Río, ${ }^{* \dagger}$ Jorge Rencoret, ${ }^{\dagger}$ Ana Gutiérrez, ${ }^{\dagger}$ Lidia Nieto, ${ }^{\ddagger}$ Jesús Jiménez-Barbero, ${ }^{\ddagger}$ and Ángel T. Martínez ${ }^{\ddagger}$ \\ ${ }^{\dagger}$ Instituto de Recursos Naturales y Agrobiología de Sevilla (IRNAS), CSIC, P.O. Box 1052, E-41080 Seville, Spain \\ ${ }^{\ddagger}$ Centro de Investigaciones Biológicas (CIB), CSIC, Ramiro de Maeztu 9, E-28040 Madrid, Spain
}

ABSTRACT: The structural characteristics of the lignins from flax (Linum usitatissimum) fibers and shives were studied. Significant differences in the content and composition of the lignin from both parts were observed. The lignin contents were $3.8 \%$ in the fibers and 29.0\% in the shives. Analysis by Py-GC/MS indicated a H:G:S molar ratio of 13:72:15 in the milled wood lignin (MWL) isolated from flax fibers and a molar ratio of 5:87:8 in the MWL isolated from flax shives. In addition, 2D-NMR showed a predominance of $\beta-O-4^{\prime}$ aryl ether linkages, followed by $\beta-5^{\prime}$ phenylcoumaran and $\beta-\beta^{\prime}$ resinol-type linkages in both MWLs, with a higher content of condensed linkages in flax shives. Thioacidolysis (followed by Raney nickel desulfurization) gave further information on the lignin units involved in the different linkages and confirmed the enrichment of $\mathrm{G}$ units. The thioacidolysis dimers released were similar from both lignins, with a predominance of the $\beta-5^{\prime}$ followed by $\beta-1^{\prime}$ and $5-5^{\prime}$ structures.

KEYWORDS: flax, Linum usitatissimum, fibers, shives, Py-GC/MS, HSQC, thioacidolysis, milled wood lignin

\section{INTRODUCTION}

There is a growing need to consider alternative agricultural strategies that move an agricultural industry focused on food production to one that also supplies the needs of other industrial sectors, such as paper, textiles, biofuels, or added-value chemicals. ${ }^{1,2}$ Nonwoody plant biomass from field crops and agricultural residues could become important raw materials in this transformation. ${ }^{1-3}$ The main sources of nonwoody raw materials are agricultural residues from monocotyledons, including cereal straw and bagasse, or plants grown specifically for fiber, such as bamboo, reeds, or elephant grass, and some other plants such as flax, hemp, kenaf, jute, sisal, or abaca. Nonwoody plants offer several advantages including short growth cycles, moderate irrigation requirements, and, in most cases, low lignin contents, which in principle would result in reduced energy and chemical consumption during lignin removal.

Flax (Linum usitatissimum) is an important annual plant from the Linaceae family that is commercially grown worldwide both for its seeds and for its fibers. Flax fibers have been used for linen textiles since Egyptian times. In addition, the fibers also provided natural raw materials for composites and the manufacturing of high-quality pulps for specialty papers (i.e., paper for cigarettes, tea bags, currency, prayer books, artwork, stock and bond certificates, etc.). ${ }^{3,4}$ Flax plants have two regions in the stem: an outer portion formed by long bast fibers and a core containing short fibers. Flax fibers are extracted from the bast or skin of the stem of the plant by a process called retting, which consists of the separation of bast fibers from the core tissues. When flax fibers are extracted from flax straw, the nonfiber parts of the stem, not including the seed, are normally referred to as shives. By weight, the core flax fiber (shives) represents up to $75 \%$ of the content of the flax stem. The yield of shives is 2.5 tons for every ton of fiber produced $^{5}$ and is mostly discarded or burned. However, there is a growing interest to add value to the flax shives, and their further conversion into biofuels and other bioproducts represents an excellent opportunity. ${ }^{6-8}$
To maximize the exploitation of flax fibers and shives as a source of biomass for the production of textiles, paper pulps, biofuels, or chemicals, a complete understanding of their chemistry is required, including the detailed chemical composition. Previous studies reported significant differences in the chemical composition of flax bast fibers and shives. ${ }^{6,8}$ These studies indicated that flax fibers are low in lignin (ca. 5\%) and hemicelluloses (ca. 6\%) and high in cellulose (ca. 78\%) content, whereas flax shives contain more lignin $(23-31 \%)$, more hemicelluloses $(13-26 \%)$, and less cellulose (34-53\%) than the fiber. Despite the high differences in lignin content among bast fibers and shives, studies regarding the detailed composition and structure of the lignins in both parts have been scarce. ${ }^{9-13}$

The aim of the present study is, therefore, to get further insight into the composition and structure of the lignins from flax bast fibers and shives. The composition of the lignin in flax fibers was already addressed in our laboratories by in situ pyrolysis-gas chromatography - mass spectrometry (Py-GC/MS) of the whole cell walls, without previous lignin isolation; ${ }^{11}$ however, the extremely low lignin content in the fibers (ca. 3\%) made evaluation of the results extremely difficult and hindered the direct comparison with the in situ analysis of the lignin in flax shives. Indeed, this low lignin content is also a limitation for the in situ analysis by other methods, such as NMR. Therefore, to obtain detailed and comparable information on the composition and structure of the lignins from flax fibers and shives, we isolated the so-called milled wood lignins (MWL) according to classical procedures ${ }^{14}$ and subsequently characterized them by Py-GC/MS, two-dimensional nuclear magnetic resonance spectroscopy (2D-NMR), and thioacidolysis (followed by Raney nickel desulfurization). Py-GC/MS is a rapid and highly sensitive technique for

Received: March 28, 2011

Revised: $\quad$ August 22, 2011

Accepted: September 9, 2011

Published: September 09, 2011 
characterizing the chemical composition of lignins in terms of their $p$-hydroxyphenyl $(\mathrm{H})$, guaiacyl $(\mathrm{G})$, and syringyl (S) units. ${ }^{11,12,15-20} 2 \mathrm{D}-\mathrm{NMR}$, on the other hand, provides information of the structure of the whole macromolecule and is a powerful tool for lignin structural characterization revealing both the aromatic units and the different interunit linkages present in the lignin polymer. ${ }^{18-29}$ Finally, thioacidolysis is a selective chemical degradative method that cleaves the most frequent interunit linkage in lignin, that is, the $\beta-O-4^{\prime}$ ether linkage. The total yields and relative distribution of the thioacidolysis monomers reflect the amount and ring type of lignin units involved in these alkyl-aryl ether bonds. In addition, the dimers recovered after thioacidolysis can provide information about the units involved in the various carbon-carbon and diaryl ether linkages, often referred to as the "condensed" bonds (including 5-5', 4-O$5^{\prime}, \beta-1^{\prime}, \beta-5^{\prime}$, and $\left.\beta-\beta^{\prime}\right) .{ }^{18,19,27,30-33}$ Knowledge of the composition and structure of the lignin polymer of flax fibers and shives will help to maximize the industrial exploitation of this interesting crop.

\section{MATERIALS AND METHODS}

Samples. Flax (L. usitatissimum) bast fibers and shives (cultivar Hermes) were supplied by CELESA pulp mill (Tortosa, Spain) and were carefully separated by hand. Flax fibers and shives were air-dried and milled using an IKA cutting mill to pass through a 100-mesh screen. The milled samples were successively extracted with acetone in a Soxhlet apparatus for $8 \mathrm{~h}$ and then with hot water $\left(3 \mathrm{~h}\right.$ at $\left.100^{\circ} \mathrm{C}\right)$. Klason lignin content was estimated as the residue after sulfuric acid hydrolysis of the pre-extracted material according to Tappi rule T222 om- $88 .^{34}$ Two replicates were used for each sample. The relative standard deviation for the Klason lignin determination was $<5 \%$.

Lignin Isolation. The MWL samples were obtained according to the classical procedure. ${ }^{14}$ Extractive-free ground samples ( $25 \mathrm{~g}$, prepared as described above) were finely ball-milled in a Retsch PM100 planetary ball mill ( $50 \mathrm{~h}$ at $300 \mathrm{rpm}$, with cycles of $20 \mathrm{~min}$ of milling and $25 \mathrm{~min}$ of rest to let the jar cool) using an agate jar $(500 \mathrm{~mL})$ and agate ball bearings $(20 \times 20 \mathrm{~mm})$ and toluene as coolant. After this treatment, the ball-milled samples were submitted to an extraction $(4 \times 24 \mathrm{~h})$ with dioxane/water $(9: 1, \mathrm{v} / \mathrm{v})(5-10 \mathrm{~mL}$ solvent/g milled sample). The solution was centrifuged and the supernatant evaporated at $40{ }^{\circ} \mathrm{C}$ at reduced pressure. The residue obtained (raw MWL) was redissolved in a solution of acetic acid/water 9:1 (v/v) $(20 \mathrm{~mL}$ solvent/g raw milled wood lignin). The solution was precipitated into water, and the residue was separated by centrifugation, milled in an agate mortar, and dissolved in a solution of 1,2-dichloromethane/ethanol $(1: 2, \mathrm{v} / \mathrm{v})$. The mixture was then centrifuged to eliminate the insoluble material. The resulting supernatant was precipitated in diethyl ether, and the obtained residue was separated by centrifugation. This residue was then resuspended in petroleum ether and centrifuged again to obtain the final purified MWL fraction, which was dried under a current of $\mathrm{N}_{2}$. The final yields ranged from 10 to $15 \%$ of the original Klason lignin content. Extension of milling time, which would increase yield, was avoided to prevent chemical modifications on the lignin structure. The purity of the MWL preparations was investigated by analyzing their lignin content by the acetyl bromide method. ${ }^{35}$

Gel Permeation Chromatography (GPC). GPC was performed on a Shimadzu LC-20A LC system (Shimadzu, Kyoto, Japan) equipped with a photodiode array (PDA) detector (SPD-M20A; Shimadzu) using the following conditions: column, TSK gel $\alpha-\mathrm{M}+\alpha-2500$ (Tosoh, Tokyo, Japan); eluent, 0.1 M LiBr in dimethylformamide (DMF); flow rate, $0.5 \mathrm{~mL} \mathrm{~min}^{-1}$; column oven temperature, $40^{\circ} \mathrm{C}$; sample detection, PDA response at $280 \mathrm{~nm}$. The data acquisition and computation used
LCsolution version 1.25 software (Shimadzu). The molecular weight calibration was via polystyrene standards.

Analytical Pyrolysis. Pyrolysis of the MWL isolated from flax fibers and shives (approximately $100 \mu \mathrm{g}$ ) was performed with a 2020 microfurnace pyrolyzer (Frontier Laboratories Ltd.) connected to an Agilent 6890 GC-MS system equipped with a DB-1701 fused-silica capillary column $(30 \mathrm{~m} \times 0.25 \mathrm{~mm}$ i.d., $0.25 \mu \mathrm{m}$ film thickness $)$ and an Agilent 5973 mass selective detector (EI at $70 \mathrm{eV}$ ). The pyrolysis was performed at $500{ }^{\circ} \mathrm{C}$. The oven temperature was programmed from $50{ }^{\circ} \mathrm{C}(1 \mathrm{~min})$ to 100 at $30{ }^{\circ} \mathrm{C} \mathrm{min}^{-1}$ and then to $290{ }^{\circ} \mathrm{C}(10 \mathrm{~min})$ at $6{ }^{\circ} \mathrm{C} \mathrm{min}{ }^{-1}$. Helium was the carrier gas $\left(1 \mathrm{~mL} \mathrm{~min}^{-1}\right)$. The compounds were identified by comparing their mass spectra with those of the Wiley and NIST libraries and those reported in the literature. ${ }^{15-18}$ Peak molar areas were calculated for the lignin degradation products, the summed areas were normalized, and the data for two repetitive analyses were averaged and expressed as percentages. The relative standard deviation for the pyrolysis data was $<5 \%$.

NMR Spectroscopy. NMR spectra of the MWL from flax fibers and shives were recorded at $25{ }^{\circ} \mathrm{C}$ on a Bruker AVANCE $500 \mathrm{MHz}$ equipped with a $z$-gradient triple-resonance probe. Around $40 \mathrm{mg}$ of MWL was dissolved in $0.75 \mathrm{~mL}$ of deuterated dimethyl sulfoxide $\left(\mathrm{DMSO}-d_{6}\right)$, and 2D-NMR spectra were recorded in heteronuclear single-quantum correlation (HSQC) experiments. The spectral widths were 5000 and $13200 \mathrm{~Hz}$ for the ${ }^{1} \mathrm{H}$ and ${ }^{13} \mathrm{C}$ dimensions, respectively. The number of collected complex points was 2048 for the ${ }^{1} \mathrm{H}$ dimension with a recycle delay of $5 \mathrm{~s}$. The number of transients was 64 , and 256 time increments were always recorded in the ${ }^{13} \mathrm{C}$ dimension. The ${ }^{1} J_{\mathrm{CH}}$ used was $140 \mathrm{~Hz}$. The $J$-coupling evolution delay was set to $3.2 \mathrm{~ms}$. A squared cosine-bell apodization function was applied in both dimensions. Prior to Fourier transformation, the data matrices were zero filled to 1024 points in the ${ }^{13} \mathrm{C}$ - dimension. The central solvent peak was used as an internal reference $\left(\delta_{\mathrm{C}} 39.5 ; \delta_{\mathrm{H}} 2.49\right)$. HSQC cross-signals were assigned by comparison with the literature. ${ }^{18-20,22-29}$ A semiquantitative analysis of the intensities of the HSQC cross-signal intensities was performed. ${ }^{22}$ Because the cross-signal intensity depends on the particular ${ }^{1} J_{\mathrm{CH}}$ value, as well on the $T_{2}$ relaxation time, a direct analysis of the intensities is impossible. Thus, the integration on the cross-signals was performed separately for the different regions of the HSQC spectrum, which contain signals that correspond to chemically analogous carbon-proton pairs. For these signals, the ${ }^{1} J_{\mathrm{CH}^{-}}$-coupling value is relatively similar and can be used semiquantitatively to estimate the relative abundance of the different species. In the aliphatic oxygenated region, the relative abundance of side chains involved in the different interunit linkages was estimated from the $\mathrm{C}_{\alpha}-\mathrm{H}_{\alpha}$ correlations to avoid possible interference from homonuclear ${ }^{1} \mathrm{H}-{ }^{1} \mathrm{H}$ couplings, except for structure $\mathbf{I}$, where $\mathrm{C}_{\gamma}-\mathrm{H}_{\gamma}$ correlations were used, and the relative abundance of side chains involved in different substructures and terminal structures was calculated (with respect to total side chains). In the aromatic region, $\mathrm{C}-\mathrm{H}$ correlations from $\mathrm{H}, \mathrm{G}$, and $\mathrm{S}$ units were used to estimate the lignin $\mathrm{H}: \mathrm{G}: \mathrm{S}$ ratio, and the comparison of the intensities of the $\mathrm{C}_{\beta}-\mathrm{H}_{\beta}$ correlations of structuresI and $\mathbf{J}$ was used to estimate the abundances of the latter.

Thioacidolysis followed by Raney Nickel Desulfurization. Thioacidolysis of $5 \mathrm{mg}$ of MWL was performed as described by Rolando et al. ${ }^{32}$ using $0.2 \mathrm{M} \mathrm{BF}_{3}$ etherate in dioxane/ethanethiol (8.75:1). The reactions products were extracted with $\mathrm{CH}_{2} \mathrm{Cl}_{2}$, dried, and concentrated. Two-hundred microliters of the $\mathrm{CH}_{2} \mathrm{Cl}_{2}$ solution containing the thioacidolysis products was desulfurated as described by Lapierre et al. ${ }^{30} \mathrm{GC}$ MS analysis of the monomeric and dimeric compounds was performed in a Varian Star 3400 instrument coupled to an ion-trap detector Varian Saturn 2000, using a DB-5HT fused-silica capillary column from J\&W Scientific ( $30 \mathrm{~m} \times 0.25 \mathrm{~mm}$ i.d., $0.1 \mu \mathrm{m}$ film thickness). The temperature was programmed from 50 to $110{ }^{\circ} \mathrm{C}$ at $30^{\circ} \mathrm{C} / \mathrm{min}$ and then to $320{ }^{\circ} \mathrm{C}(13 \mathrm{~min})$ at $6{ }^{\circ} \mathrm{C} / \mathrm{min}$. The injector and transfer line were 
Table 1. Weight-Average $\left(M_{\mathrm{w}}\right)$ and Number-Average $\left(M_{\mathrm{n}}\right)$ Molecular Weights and Polydispersity $\left(M_{w} / M_{n}\right)$ of the MWLs Isolated from Flax (L. usitatissimum) Fibers and Shives

\begin{tabular}{lcc} 
& flax fiber MWL & flax shive MWL \\
$M_{\mathrm{w}}\left(\mathrm{g} \mathrm{mol}^{-1}\right)$ & 7620 & 8825 \\
$M_{\mathrm{n}}\left(\mathrm{g} \mathrm{mol}^{-1}\right)$ & 2123 & 2337 \\
$M_{\mathrm{w}} / M_{\mathrm{n}}$ & 3.59 & 3.77 \\
\hline
\end{tabular}
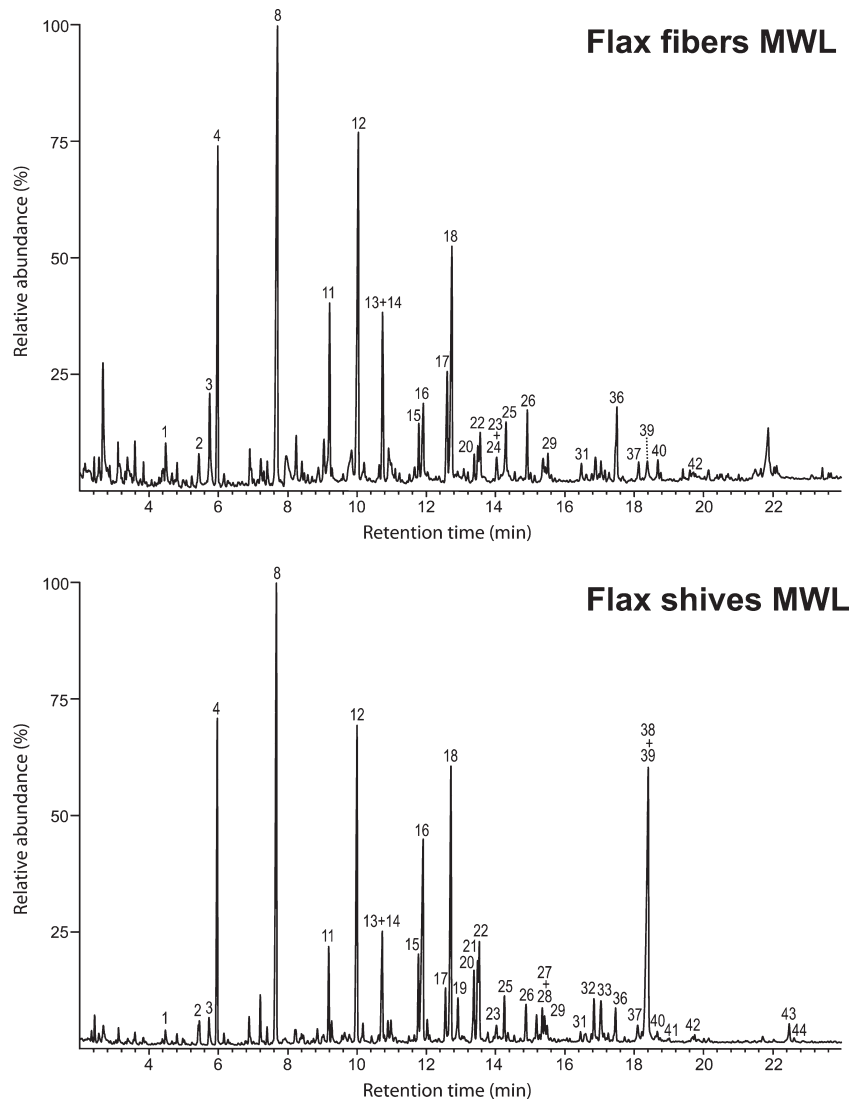

Figure 1. Py-GC/MS chromatograms of the MWL isolated from flax (L. usitatissimum) fibers and shives. The identities and relative abundances of the released compounds are listed in Table 2.

at $300{ }^{\circ} \mathrm{C}$. Helium was the carrier gas $(2 \mathrm{~mL} / \mathrm{min})$, and octadecane was used as internal standard. Dimer identification was based on previously reported mass spectra ${ }^{18,19,27,30,33}$ and mass fragmentography.

\section{RESULTS AND DISCUSSION}

The lignin contents in flax bast fibers and shives were estimated according to the Klason method and revealed a low lignin content in the fibers (3.8\%) and a high lignin content in the shives $(29.0 \%)$. These values agree well with previous results that indicated low lignin content in flax bast fibers in the range of 1.4-4.2\% and a high lignin content in flax shives in the range of $23.7-31.4 \%{ }^{6,8,13,36}$ The lignin content in flax bast fibers is lower than in other bast fibers, such as hemp (4.6\%), jute (13.3\%), or kenaf $(11.4 \%) .{ }^{18,37,38}$ This low lignin content observed in flax bast fiber has prompted some authors to conclude that flax bast fibers do not contain lignin and that the Klason lignin content determined was mainly due to contamination from residual shives or epidermis/cuticle material remaining after the retting
Table 2. Identification and Relative Molar Abundance of the Lignin-Derived Compounds Identified in the Py-GC/MS of the MLWs from Flax (L. usitatissimum) Fibers and Shives

\begin{tabular}{|c|c|c|c|}
\hline no. & compound & $\begin{array}{c}\text { flax fiber } \\
\text { MWL }\end{array}$ & $\begin{array}{c}\text { flax shive } \\
\text { MWL }\end{array}$ \\
\hline 1 & phenol & 2.0 & 0.8 \\
\hline 2 & methylphenol & 1.5 & 0.7 \\
\hline 3 & methylphenol & 4.7 & 1.4 \\
\hline 4 & guaiacol & 12.1 & 9.8 \\
\hline 5 & C2-phenol & 1.7 & 1.0 \\
\hline 6 & C2-phenol & 0.8 & 0.1 \\
\hline 7 & C2-phenol & 0.4 & 0.1 \\
\hline 8 & 4-methylguaiacol & 19.7 & 16.7 \\
\hline 9 & 4-vinylphenol & 1.8 & 0.4 \\
\hline 10 & C3-phenol & 0.0 & 0.4 \\
\hline 11 & 4-ethylguaiacol & 5.0 & 2.5 \\
\hline 12 & 4-vinylguaiacol & 13.7 & 10.6 \\
\hline 13 & syringol & 3.2 & 1.3 \\
\hline 14 & eugenol & 1.8 & 2.3 \\
\hline 15 & (Z)-isoeugenol & 1.3 & 2.0 \\
\hline 16 & vanillin & 2.9 & 9.0 \\
\hline 17 & 4-methylsyringol & 3.3 & 1.4 \\
\hline 18 & (E)-isoeugenol & 8.0 & 8.5 \\
\hline 19 & homovanillin & 0.0 & 1.4 \\
\hline 20 & propyneguaiacol & 0.8 & 2.2 \\
\hline 21 & propyneguaiacol & 1.1 & 2.3 \\
\hline 22 & acetoguaiacone & 1.5 & 2.5 \\
\hline 23 & vanillic acid methyl ester & 0.2 & 0.3 \\
\hline 24 & 4-ethylsyringol & 0.5 & 0.1 \\
\hline 25 & guaiacylacetone & 1.7 & 1.1 \\
\hline 26 & 4-vinylsyringol & 1.7 & 1.0 \\
\hline 27 & propiovanillone & 0.8 & 0.7 \\
\hline 28 & guaiacyl vinyl ketone & 0.3 & 0.6 \\
\hline 29 & 4-allylsyringol & 0.5 & 0.3 \\
\hline 30 & 4-propylsyringol & 0.1 & 0.1 \\
\hline 31 & (Z)-4-propenylsyringol & 0.5 & 0.2 \\
\hline 32 & syringaldehyde & 0.8 & 1.1 \\
\hline 33 & $(Z)$-coniferyl alcohol & 0.1 & 1.4 \\
\hline 34 & propynesyringol & 0.3 & 0.1 \\
\hline 35 & propynesyringol & 0.3 & 0.2 \\
\hline 36 & (E)-4-propenylsyringol & 2.5 & 0.9 \\
\hline 37 & acetosyringone & 0.6 & 0.6 \\
\hline 38 & (E)-coniferaldehyde & 0.0 & 8.3 \\
\hline 39 & (E)-coniferyl alcohol & 0.9 & 4.7 \\
\hline 40 & syringylacetone & 0.5 & 0.2 \\
\hline 41 & syringic acid methyl ester & 0.2 & 0.1 \\
\hline 42 & propiosyringone & 0.1 & 0.2 \\
\hline 43 & (E)-sinapaldehyde & 0.0 & 0.6 \\
\hline \multirow[t]{6}{*}{44} & (E)-sinapyl alcohol & 0.0 & 0.1 \\
\hline & $\% \mathrm{H}$ & 13.1 & 4.8 \\
\hline & $\% \mathrm{G}$ & 71.9 & 86.8 \\
\hline & $\% \mathrm{~S}$ & 15.1 & 8.4 \\
\hline & $S / G$ & 0.21 & 0.10 \\
\hline & $\mathrm{H} / \mathrm{G}$ & 0.18 & 0.05 \\
\hline
\end{tabular}




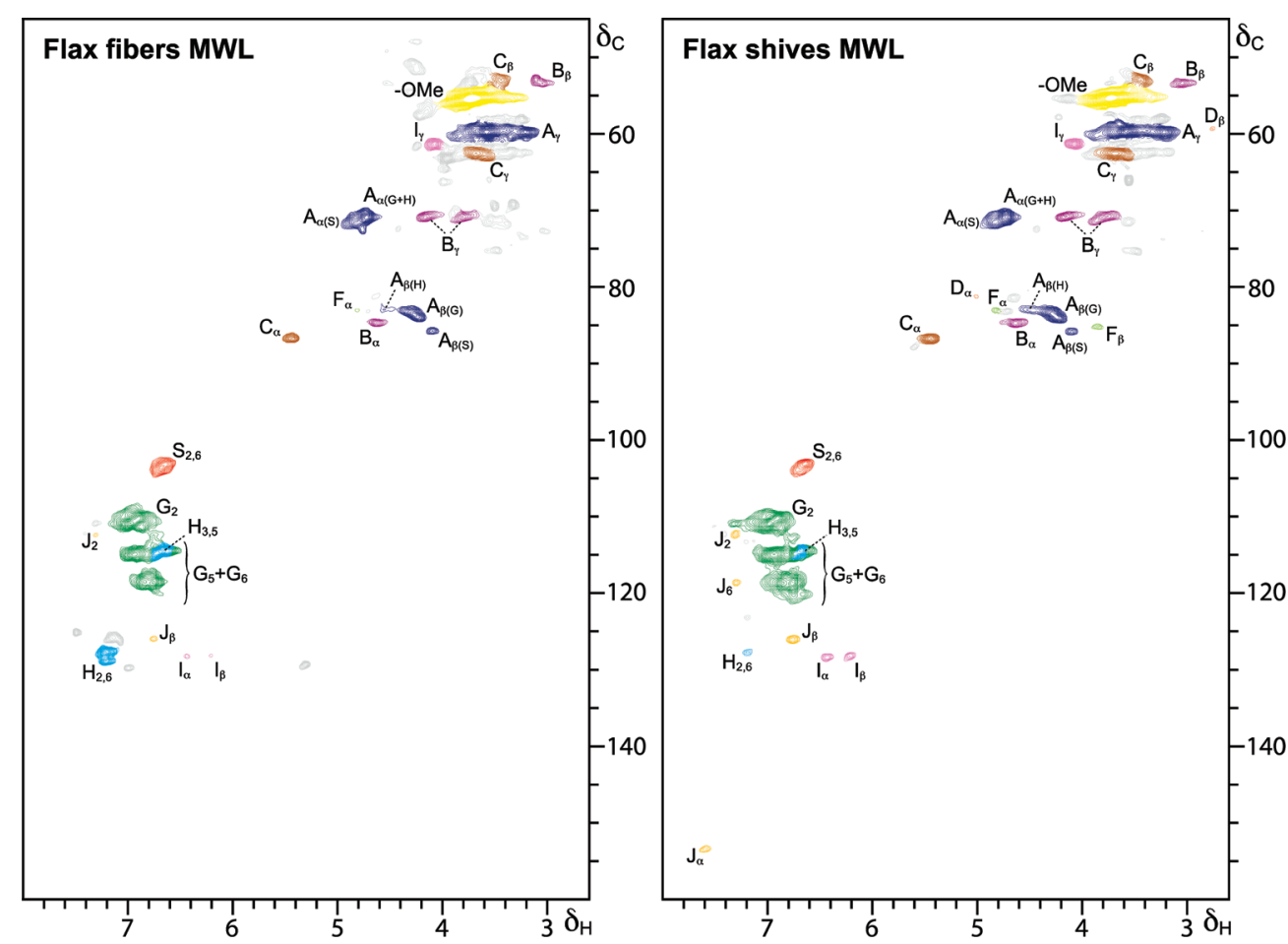

Figure 2. HSQC NMR spectra $\left(\delta_{\mathrm{C}} / \delta_{\mathrm{H}} 45-160 / 2.6-8.0\right)$ of the MWLs isolated from flax (L. usitatissimum) fibers and shives. See Table 3 for signal assignment and Figure 3 for the main lignin structures identified.

processes."10 However, later studies unambiguously demonstrated the presence of this low lignin content in flax bast fibers by immunological and chemical (thioacidolysis and nitrobenzene oxidation) analyses, ${ }^{13}$ in agreement with our present results.

The composition of the lignin in flax fibers has already been addressed by Py-GC/MS of the whole cell walls, without previous lignin isolation; ${ }^{11}$ however, the low lignin content avoids the in situ analysis of this lignin by other methods, such as NMR, and the direct comparison with the in situ analysis of the lignin in flax shives impossible. Therefore, to obtain detailed information on the composition and structure of the flax lignins, the MWL, a lignin preparation considered to be the most representative of the whole native lignin in the plant, ${ }^{14}$ despite its low yield and the possibility of some modifications during milling, ${ }^{39}$ was isolated from both flax fibers and shives and subsequently characterized by several analytical techniques, including GPC, Py-GC/MS, 2D-NMR, and thioacidolysis (followed by Raney nickel desulfurization). However, we must keep in mind that the results obtained here reflect only the structure of isolated MWL, which represents a part of the whole lignin in the plant.

Molecular Weight Distributions. The values of the weightaverage $\left(M_{\mathrm{w}}\right)$ and number-average $\left(M_{\mathrm{n}}\right)$ molecular weights, estimated from the GPC curves (relative values related to polystyrene), and the polydispersity $\left(M_{\mathrm{w}} / M_{\mathrm{n}}\right)$ of the MWL from flax fibers and shives are indicated in Table 1. The two MWLs exhibited similar molecular weight distributions, in the range of $8825-7620 \mathrm{~g} \mathrm{~mol}^{-1}$, being slightly higher in the case of the MWL from flax shives. In addition, both MWLs exhibited relatively narrow molecular weight distributions, with $M_{\mathrm{w}} / M_{\mathrm{n}}$ $<4$. Those values are comparable to literature values for various isolated lignins. $^{40}$
Py-GC/MS of the MWLs from Flax Bast Fibers and Shives. The Py-GC/MS chromatograms of the MWLs isolated from flax bast fibers and shives are shown in Figure 1, and the identities and relative abundances of the released compounds are listed in Table 2. The pyrograms showed compounds derived from $H, G$, and $S$ lignin units, the main lignin-derived compounds released being guaiacol (4), 4-methylguaiacol (8), 4-ethylguaiacol (11), 4-vinylguaiacol (12), vanillin (16), syringol (13), (E)-isoeugenol (18), and 4-methylsyringol (17). High amounts of $(E)$-coniferaldehyde (38) and (E)-coniferyl alcohol (39) were also released from the flax shive lignin but were minor compounds among the pyrolysates of flax fiber lignin. In both MWLs, the lignin-derived G-type phenols were present in higher abundances than the respective $\mathrm{H}$ - and S-type phenols, with $\mathrm{H}: \mathrm{G}: \mathrm{S}$ compositions of 13:72:15 and 5:87:8 for the MWL from flax fibers and shives, respectively. The $S / G$ ratios were low in both cases, with a ratio of 0.21 for the fibers and 0.10 for the shives. The $S / G$ ratio of the flax bast lignin agrees well with the values estimated upon in situ Py-GC/MS of flax fibers, without previous lignin isolation. ${ }^{11}$ Flax bast fibers present the lowest $S / G$ ratio when compared to other bast fibers, such as those of hemp (0.64), jute (2.1), or kenaf (5.4). ${ }^{11,12,18,26,28,37,38,41}$ The content of $\mathrm{H}$ units was high, especially in the lignin from flax bast fibers, having a $13 \%$ content of $\mathrm{H}$ units. Important amounts of $\mathrm{H}$-lignin units $(13-25 \%$ of all lignin units) were also released from flax bast fibers by nitrobenzene oxidation of whole cell walls, in contrast to only $1 \% \mathrm{H}$ units released from flax shives. ${ }^{13}$ High contents of $\mathrm{H}$-lignin units were also reported in hemp bast fibers. ${ }^{28,38}$

The high G-lignin content observed in flax fibers, and especially in flax shives, makes these lignins highly recalcitrant toward depolymerization. This may affect some uses of these raw materials, such as the delignification stages during alkaline pulping, due to the lower reactivity of the G-lignin compared to S-lignin in 
Table 3. Assignments of the Lignin ${ }^{13} \mathrm{C}-{ }^{1} \mathrm{H}$ Correlation Signals in the HSQC Spectra of the MWLs from Flax (L. usitatissimum) Fibers and Shives

\begin{tabular}{|c|c|c|}
\hline label & $\delta_{\mathrm{C}} / \delta_{\mathrm{H}}$ & assignment \\
\hline $\mathrm{C}_{\beta}$ & $53.5 / 3.46$ & $\mathrm{C}_{\beta}-\mathrm{H}_{\beta}$ in phenylcoumaran substructures $(\mathrm{C})$ \\
\hline $\mathrm{B}_{\beta}$ & $53.5 / 3.06$ & $\mathrm{C}_{\beta}-\mathrm{H}_{\beta}$ in resinol substructures (B) \\
\hline$-\mathrm{OMe}$ & $55.6 / 3.73$ & $\mathrm{C}-\mathrm{H}$ in methoxyls \\
\hline $\mathrm{A}_{\gamma}$ & $\begin{array}{r}59.4 / 3.40 \\
\text { and } 3.72\end{array}$ & $\mathrm{C}_{\gamma}-\mathrm{H}_{\gamma}$ in $\beta-O-4^{\prime}$ substructures (A) \\
\hline $\mathrm{D}_{\beta}$ & $59.6 / 2.75$ & $\mathrm{C}_{\beta}-\mathrm{H}_{\beta}$ in spirodienone substructures (D) \\
\hline $\mathrm{I}_{\gamma}$ & $61.3 / 4.09$ & $\mathrm{C}_{\gamma}-\mathrm{H}_{\gamma}$ in cinnamyl alcohol end-groups (I) \\
\hline $\mathrm{C}_{\gamma}$ & $62.5 / 3.72$ & $\mathrm{C}_{\gamma}-\mathrm{H}_{\gamma}$ in phenylcoumaran substructures $(\mathrm{C})$ \\
\hline $\mathrm{A}_{\alpha(\mathrm{G})}$ & $71.0 / 4.74$ & $\mathrm{C}_{\alpha}-\mathrm{H}_{\alpha}$ in $\beta-O-4^{\prime}$ linked to a $\mathrm{G}$ unit (A) \\
\hline $\mathrm{B}_{\gamma}$ & $\begin{array}{r}71.0 / 3.83 \\
\text { and } 4.19\end{array}$ & $\mathrm{C}_{\gamma}-\mathrm{H}_{\gamma}$ in resinol substructures (B) \\
\hline $\mathrm{A}_{\alpha(\mathrm{s})}$ & $71.6 / 4.86$ & $\mathrm{C}_{\alpha}-\mathrm{H}_{\alpha}$ in $\beta-O-4^{\prime}$ linked to a $\mathrm{S}$ unit (A) \\
\hline $\mathrm{D}_{\alpha}$ & $81.2 / 5.09$ & $\mathrm{C}_{\alpha}-\mathrm{H}_{\alpha}$ in spirodienone substructures (D) \\
\hline $\mathrm{A}_{\beta(\mathrm{H})}$ & $82.9 / 4.48$ & $\mathrm{C}_{\beta}-\mathrm{H}_{\beta}$ in $\beta-O-4^{\prime}$ linked to a $\mathrm{H}$ unit (A) \\
\hline $\mathrm{F}_{\alpha}$ & $83.0 / 4.82$ & $\begin{array}{l}\mathrm{C}_{\alpha}-\mathrm{H}_{\alpha} \text { in } 5-5^{\prime} \text { (dibenzodioxocin) } \\
\quad \text { substructures }(\mathrm{F})\end{array}$ \\
\hline $\mathrm{A}_{\beta(\mathrm{G})}$ & $83.5 / 4.28$ & $\mathrm{C}_{\beta}-\mathrm{H}_{\beta}$ in $\beta-O-4^{\prime}$ linked to a $\mathrm{G}$ unit (A) \\
\hline $\mathrm{B}_{\alpha}$ & $84.8 / 4.67$ & $\mathrm{C}_{\alpha}-\mathrm{H}_{\alpha}$ in resinol substructures (B) \\
\hline $\mathrm{F}_{\beta}$ & $85.2 / 3.85$ & $\begin{array}{l}\mathrm{C}_{\beta}-\mathrm{H}_{\beta} \text { in } 5-5^{\prime} \text { (dibenzodioxocin) } \\
\text { substructures }(\mathrm{F})\end{array}$ \\
\hline $\mathrm{D}_{\alpha^{\prime}}$ & $84.8 / 4.75$ & $\mathrm{C}_{\alpha^{\prime}} \mathrm{H}_{\alpha^{\prime}}$ in spirodienone substructures (D) \\
\hline $\mathrm{A}_{\beta(S)}$ & $85.8 / 4.11$ & $\mathrm{C}_{\beta}-\mathrm{H}_{\beta}$ in $\beta-O-4^{\prime}$ linked to a $\mathrm{S}$ unit (A) \\
\hline $\mathrm{C}_{\alpha}$ & $86.8 / 5.45$ & $\mathrm{C}_{\alpha}-\mathrm{H}_{\alpha}$ in phenylcoumaran substructures (C) \\
\hline$S_{2,6}$ & $103.8 / 6.69$ & $\mathrm{C}_{2,6}-\mathrm{H}_{2,6}$ in etherified syringyl units $(\mathrm{S})$ \\
\hline $\mathrm{G}_{2}$ & $110.9 / 6.99$ & $\mathrm{C}_{2}-\mathrm{H}_{2}$ in guaiacyl units $(\mathrm{G})$ \\
\hline $\mathrm{J}_{2(\mathrm{G})}$ & $112.2 / 7.42$ & $\mathrm{C}_{2}-\mathrm{H}_{2}$ in cinnamyl aldehyde end-groups $(\mathrm{J})$ \\
\hline $\mathrm{H}_{3,5}$ & $114.9 / 6.74$ & $\mathrm{C}_{3,5}-\mathrm{H}_{3,5}$ in $p$-hydroxyphenyl units $(\mathrm{H})$ \\
\hline $\mathrm{G}_{5} / \mathrm{G}_{6}$ & $\begin{array}{c}114.9 / 6.72 \\
\text { and } 6.94 \\
118.7 / 6.77\end{array}$ & $\mathrm{C}_{5}-\mathrm{H}_{5}$ and $\mathrm{C}_{6}-\mathrm{H}_{6}$ in guaiacyl units $(\mathrm{G})$ \\
\hline $\mathrm{J}_{6}(\mathrm{G})$ & $123.2 / 7.19$ & $\mathrm{C}_{6}-\mathrm{H}_{6}$ in cinnamyl aldehyde end-groups $(\mathrm{J})$ \\
\hline $\mathrm{H}_{2,6}$ & $128.0 / 7.23$ & $\mathrm{C}_{2,6}-\mathrm{H}_{2,6}$ in $p$-hydroxyphenyl units $(\mathrm{H})$ \\
\hline $\mathrm{J}_{\beta}$ & $126.1 / 6.76$ & $\mathrm{C}_{\beta}-\mathrm{H}_{\beta}$ in cinnamyl aldehyde end-groups $(\mathrm{J})$ \\
\hline $\mathrm{I}_{\beta}$ & $128.4 / 6.23$ & $\mathrm{C}_{\beta}-\mathrm{H}_{\beta}$ in cinnamyl alcohol end-groups (I) \\
\hline $\mathrm{I}_{\alpha}$ & $128.4 / 6.45$ & $\mathrm{C}_{\alpha}-\mathrm{H}_{\alpha}$ in cinnamyl alcohol end-groups (I) \\
\hline $\mathrm{J}_{\alpha}$ & $153.4 / 7.61$ & $\mathrm{C}_{\alpha}-\mathrm{H}_{\alpha}$ in cinnamyl aldehyde end-groups $(\mathrm{J})$ \\
\hline
\end{tabular}

alkaline systems. ${ }^{42}$ The $\mathrm{G}$ units have a free C-5 position available for additional carbon-carbon or ether interunit bonds, which makes them fairly resistant to lignin depolymerization during alkaline pulping. Therefore, the efficiency of pulping is often directly proportional to the amount of $S$ units in lignin, and thus lower S/G ratios imply lower delignification rates, more alkali consumption, and therefore lower pulp yield. ${ }^{17,43}$ In addition, the lignin from flax bast fibers contains a high proportion of $\mathrm{H}$-units, which will also form additional linkages with both C3 and C5 positions and thus can be even more condensed than $\mathrm{G}$ units. Therefore, and despite the low lignin content present in flax bast fibers $(3.8 \%)$, its composition makes them fairly resistant to alkaline depolymerization. In the case of flax shives, its extremely high lignin content (29.0\%), together with its very low S/G ratio, makes them especially recalcitrant.
2D-NMR of the MWLs from Flax Bast Fibers and Shives. For a more complete and in-depth structural characterization of the lignins, the MWLs of flax fibers and shives were subjected to 2D-NMR analysis that provides information of the structure of the whole macromolecule and is a powerful tool for lignin structural characterization. The HSQC NMR spectra $\left(\delta_{\mathrm{C}} / \delta_{\mathrm{H}} 45-160 /\right.$ 2.6-8.0) of the MWL from flax fibers and shives are shown in Figure 2. The main lignin cross-signals in the HSQC spectra were assigned according to the literature ${ }^{18-20,22-29}$ and are listed in Table 3; the main substructures found are depicted in Figure 3.

The side-chain region of the spectra $\left(\delta_{\mathrm{C}} / \delta_{\mathrm{H}} 50-90 / 2.6-5.8\right)$ gives useful information about the different interunit linkages present in the lignin from flax fibers and shives. The spectra show prominent signals corresponding to $\beta-O-4^{\prime}$ alkyl-aryl ether linkages (substructure A). The $\mathrm{C}_{\alpha}-\mathrm{H}_{\alpha}$ correlations in $\beta-O-4^{\prime}$ substructures were observed in overlapping signals at $\delta_{\mathrm{C}} / \delta_{\mathrm{H}}$ $71.0 / 4.74$ and 71.6/4.86 for structures linked to $\mathrm{G}$ or $\mathrm{S}$ ligninunits, respectively. Likewise, the $\mathrm{C}_{\beta}-\mathrm{H}_{\beta}$ correlations were observed in signals at $\delta_{\mathrm{C}} / \delta_{\mathrm{H}} 83.5 / 4.28$ for $\beta-O-4^{\prime}$ structures linked to G-lignin units and at $\delta_{\mathrm{C}} / \delta_{\mathrm{H}} 85.8 / 4.11$ for $\beta-O-4^{\prime}$ structures linked to S-lignin units; interestingly, $\mathrm{C}_{\beta}-\mathrm{H}_{\beta}$ correlations of $\beta$ $O-4^{\prime}$ substructures linked to an $\mathrm{H}$-lignin unit could also be observed at $\delta_{\mathrm{C}} / \delta_{\mathrm{H}} 82.9 / 4.48$. The $\mathrm{C}_{\gamma}-\mathrm{H}_{\gamma}$ correlations in $\beta$ $O-4^{\prime}$ substructures were observed at $\delta_{\mathrm{C}} / \delta_{\mathrm{H}} 59.4 / 3.40$ and 3.72, partially overlapped with other signals. In addition to $\beta-O-4^{\prime}$ aryl ether substructures, cross-signals from other linkages were also observed. Thus, strong signals for resinol $\left(\beta-\beta^{\prime} / \alpha-O-\gamma^{\prime} / \gamma-O-\alpha^{\prime}\right.$ linkages) substructures (B) were observed in both spectra, with their $\mathrm{C}_{\alpha}-\mathrm{H}_{\alpha}, \mathrm{C}_{\beta}-\mathrm{H}_{\beta}$, and the double $\mathrm{C}_{\gamma}-\mathrm{H}_{\gamma}$ correlations at $\delta_{\mathrm{C}} / \delta_{\mathrm{H}} 84.8 / 4.67,53.5 / 3.06$, and $71.0 / 3.83$ and 4.19 , respectively. Phenylcoumaran $\left(\beta-5^{\prime} / \alpha-O-4^{\prime}\right.$ linkages) substructures (C) were also found in the MWL from flax fibers and shives, the signals for their $\mathrm{C}_{\alpha}-\mathrm{H}_{\alpha}$ and $\mathrm{C}_{\beta}-\mathrm{H}_{\beta}$ correlations being observed at $\delta_{\mathrm{C}} / \delta_{\mathrm{H}} 86.8 / 5.45$ and $53.5 / 3.46$, respectively, and that of $\mathrm{C}_{\gamma}-\mathrm{H}_{\gamma}$ correlation overlapping with other signals around $\delta_{\mathrm{C}} / \delta_{\mathrm{H}} 62.5 / 3.72$. Small signals corresponding to spirodienone ( $\beta-1^{\prime} / \alpha-O-\alpha^{\prime}$ linkages) substructures (D) could also be observed in the spectra, their $\mathrm{C}_{\alpha}-\mathrm{H}_{\alpha}, \mathrm{C}_{\alpha^{\prime}}-\mathrm{H}_{\alpha^{\prime}}$, and $\mathrm{C}_{\beta}-\mathrm{H}_{\beta}$ correlations being at $\delta_{\mathrm{C}} / \delta_{\mathrm{H}} 81.2 / 5.09,84.8 / 4.75$, and $59.60 / 2.75$, respectively. Interestingly, cross-signals characteristic of dibenzodioxocin $\left(5^{\prime}-5^{\prime \prime} / \alpha-O-4^{\prime} / \beta-\mathrm{O}-4^{\prime \prime}\right.$ linkages) structures (F) could also be observed in both HSQC spectra, especially in the case of the MWL from flax shives, with their $\mathrm{C}_{\alpha}-\mathrm{H}_{\alpha}$ and $\mathrm{C}_{\beta}-\mathrm{H}_{\beta}$ correlations at $\delta_{\mathrm{C}} / \delta_{\mathrm{H}} 83.0 / 4.82$ and $85.2 / 3.85$, respectively. Dibenzodioxocins are important lignin structures in softwoods, ${ }^{44,45}$ where they act as branching points, and have also been found in hardwoods, ${ }^{20,46}$ but these structures have rarely been reported in herbaceous plants. ${ }^{47}$ Their abundance in flax is related to the high $\mathrm{G}$ content of flax lignin. Finally, other signals observed in the side-chain region of the HSQC spectra are the $\mathrm{C}_{\gamma}-\mathrm{H}_{\gamma}$ correlations (at $\left.\delta_{\mathrm{C}} / \delta_{\mathrm{H}} 61.3 / 4.09\right)$ assigned to cinnamyl alcohol endgroups (I). The olefinic correlations of the cinnamyl structures were observed in the aromatic region of the spectra.

The main cross-signals in the aromatic region of the HSQC spectra $\left(\delta_{\mathrm{C}} / \delta_{\mathrm{H}} 100-160 / 6.0-8.0\right)$ corresponded mainly to the substituted benzenic rings of the different lignin units. Crosssignals from $S, G$, and $H$ lignin units could be observed in the spectra of the MWL of flax fibers and shives. The S-lignin units showed a prominent signal for the $\mathrm{C}_{2,6}-\mathrm{H}_{2,6}$ correlation at $\delta_{\mathrm{C}} /$ $\delta_{\mathrm{H}} 103.8 / 6.69$, whereas the $\mathrm{G}$ units showed different correlations for $\mathrm{C}_{2}-\mathrm{H}_{2}\left(\delta_{\mathrm{C}} / \delta_{\mathrm{H}} 110.9 / 6.99\right), \mathrm{C}_{5}-\mathrm{H}_{5}$, and $\mathrm{C}_{6}-\mathrm{H}_{6}\left(\delta_{\mathrm{C}} / \delta_{\mathrm{H}}\right.$ $114.9 / 6.72,6.94$, and $118.7 / 6.77)$. Signals of H-lignin units at 
<smiles>COc1c(C)cc(C(O)C(CO)Oc2c(C)cc(I)cc2C)cc1C</smiles>

A

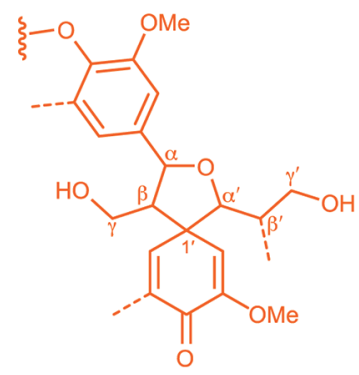

D

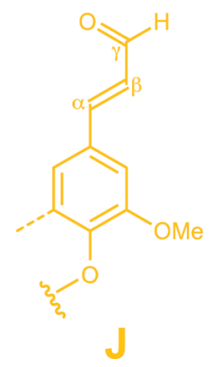<smiles>CCOc1c(C)cc([C@H]2OC[C@H]3[C@@H]2[Te]O[C@H]3c2cc(C)c(OC)c(OC)c2)cc1OC</smiles>

B<smiles>CCOc1c(C)cc(C2Oc3c(OC)cc(C)cc3[C@@H]2CO)cc1OC</smiles>

C

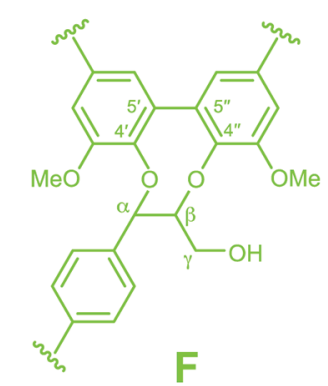

F

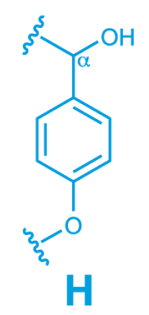

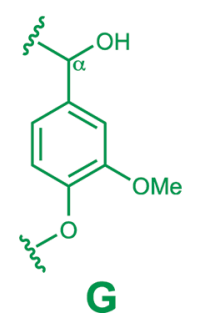<smiles>CCOc1c(C)cc(/C=C/CO)cc1OC</smiles><smiles>COc1cc(C(O)C(C)(C)C)cc(OC)c1OCS</smiles>

Figure 3. Main structures present in the lignin from flax (L. usitatissimum) fibers and shives, as revealed by HSQC 2D-NMR: (A) $\beta$-O-4' substructures; (B) resinol substructures formed by $\beta-\beta^{\prime} / \alpha-O-\gamma^{\prime} / \gamma-O-\alpha^{\prime}$ linkages; (C) phenylcoumaran substructures formed by $\beta-5^{\prime} / \alpha-O-4^{\prime}$ linkages; (D) spirodienone substructures formed by $\beta-1^{\prime} / \alpha$-O-4' linkages; (F) dibenzodioxocin substructures formed by $5^{\prime}-5^{\prime \prime} / \alpha-O-4^{\prime} / \beta$-O- $4^{\prime \prime}$ linkages; (I) cinnamyl alcohol end-groups; $(\mathrm{J})$ cinnamaldehyde end-groups; $(\mathrm{H})$ p-hydroxyphenyl unit; $(\mathrm{G})$ guaiacyl unit; $(\mathrm{S})$ syringyl unit.

$\delta_{\mathrm{C}} / \delta_{\mathrm{H}} 114.9 / 6.74$ and $128.0 / 7.23$ for $\mathrm{C}_{3,5}-\mathrm{H}_{3,5}$ and $\mathrm{C}_{2,6}-\mathrm{H}_{2,6}$, respectively, were detected in both $\mathrm{HSQC}$ spectra, the latter overlapping with $\mathrm{C}_{5}-\mathrm{H}_{5}$ in $\mathrm{G}$ units, being especially abundant in the MWL of flax fibers, as already observed by Py-GC/MS. Other signals in this HSQC region of the spectra are from cinnamyl alcohol end-groups (I), with their $\mathrm{C}_{\alpha}-\mathrm{H}_{\alpha}$ and $\mathrm{C}_{\beta}-\mathrm{H}_{\beta}$ correlations observed at $\delta_{\mathrm{C}} / \delta_{\mathrm{H}} 128.4 / 6.45$ and $128.4 / 6.23$, respectively; and cinnamaldehyde end-groups $(\mathrm{J})$, with the $\mathrm{C}_{\alpha}-\mathrm{H}_{\alpha}$ and $\mathrm{C}_{\beta}-\mathrm{H}_{\beta}$ correlations observed at $\delta_{\mathrm{C}} / \delta_{\mathrm{H}} 153.4 / 7.61$ and 126.1/ 6.76 , respectively. The total relative content of the cinnamaldehyde end-groups was estimated by comparison of the intensities of the $\mathrm{C}_{\beta}-\mathrm{H}_{\beta}$ correlations in cinnamyl alcohols (I) and aldehydes $(\mathrm{J})$. The aromatic cross-signals of the cinnamyl alcohol end-groups overlapped with the same signals in lignin $S$ and $G$ units. However, this was not the case for some of the cinnamaldehyde aromatic cross-signals revealing the presence of coniferaldehyde end-groups $\left(\mathrm{J}_{(\mathrm{G})}\right)$, characterized by $\mathrm{C}_{2}-\mathrm{H}_{2}$ and $\mathrm{C}_{6}-\mathrm{H}_{6}$ correlation signals at around $\delta_{\mathrm{C}} / \delta_{\mathrm{H}} 112.2 / 7.42$ and
123.2/7.19, respectively. These cross-signals were only evidenced in the spectrum of the MWL from flax shives.

The relative abundances of the main interunit linkages (referred to as the total side chains) present in the MWL of the flax fibers and shives, as well as the relative abundance of the $\mathrm{H}, \mathrm{G}$, and $\mathrm{S}$ units and the $\mathrm{S} / \mathrm{G}$ ratio, calculated from the HSQC spectra, are shown in Table 4, which also shows the relative abundances of the different substructures. The main substructures present in the lignin from flax bast fibers were the $\beta-O-4^{\prime}$ alkyl-aryl ether ones (A), which account for $58 \%$ of all side chains, followed by the $\beta-5^{\prime}$ phenylcoumaran structures $(\mathrm{C})$ with $11 \%$ and by the $\beta-\beta^{\prime}$ resinol substructures (B) that involved $9 \%$ of all side chains. Other lignin substructures, such as spirodienones (D) and dibenzodioxocins (F), were present in lower proportions, whereas cinnamyl end-groups $(\mathrm{I}, \mathrm{J})$ were present in relatively high abundances. The $\mathrm{H}: \mathrm{G}: \mathrm{S}$ composition determined upon NMR (15:71:14) and the $S / G$ ratio (0.20) were similar to that obtained upon Py-GC/MS, as shown above, and confirmed the high content of $\mathrm{G}$ units and the important presence of $\mathrm{H}$ units 
Table 4. Percentage of Lignin Side Chains Forming Different Interunit Linkages $(\mathrm{A}-\mathrm{F})$ and Cinnamyl Alcohol and Cinnamaldehyde End-groups (I, J), H, G, and S Contents; and S/G Ratio from Integration of ${ }^{13} \mathrm{C}-{ }^{1} \mathrm{H}$ Correlation Signals in the Side-Chain and Aromatic Regions of the HSQC Spectra of the MWLs from Flax (L. usitatissimum) Fibers and Shives

$\begin{array}{lrr} & \text { flax fiber MWL } & \text { flax shive MWL } \\ \text { linkage (and substructure) }{ }^{a} \text { relative abundances } & \\ \beta \text {-O-4' aryl ether (A) } & 58(41) & 50(33) \\ \text { resinol (B) } & 9(13) & 9(12) \\ \text { phenylcoumaran (C) } & 11(15) & 14(19) \\ \text { spirodienones (D) } & 3(4) & 4(5) \\ \text { dibenzodioxocins (F) } & 2(3) & 5(7) \\ \text { cinnamyl alcohol end-groups (I) } & 9(13) & 9(12) \\ \text { cinnamaldehyde end-groups (J) } & 8(11) & 9(12) \\ \text { percentage of lignin units } & & \\ \text { H } & 15 & 4 \\ \text { G } & 71 & 87 \\ \text { S } & 14 & 9 \\ \text { S/G ratio } & 0.20 & 0.10\end{array}$

${ }^{a}$ Substructure percentages, taking into account that two side chains are involved in one resinol-type substructure, are shown in parentheses.

in this lignin. Compared to other bast fibers, such as kenaf or jute, ${ }^{18,37}$ the lignin from flax bast fibers presents a lower S/G ratio and, consequently, a lower proportion of $\beta-O-4^{\prime}$ ether linkages, and a higher proportion of carbon-carbon linked (condensed) structures (such as $\beta-\beta^{\prime}, \beta-5^{\prime}, 5-5^{\prime}$, and $\beta-1^{\prime}$ ). Because the $\beta-O-4^{\prime}$ ether linkages are cleaved to a high extent during alkaline cooking, whereas condensed linkages resist alkaline cooking conditions, ${ }^{25,48}$ the relatively high content of condensed structures in the lignin from flax fibers will make this material more resistant to alkaline delignification than other bast fibers, despite its lower lignin content.

In the case of the lignin from flax shives, the main substructures present were also the $\beta-O-4^{\prime}$ aryl ether ones (A), which account for $50 \%$ of all side chains, followed the $\beta-5^{\prime}$ phenylcoumaran structures (C) with $14 \%$ and by the $\beta-\beta^{\prime}$ resinol substructures (B), which involved $9 \%$ of all side chains. Cinnamyl end-groups (I, J) were also present in important amounts, whereas dibenzodioxocins (F) and spirodienones (D) were present in lower amounts (4 and 5\%, respectively), although in higher proportions than in the lignin from flax bast fibers. The $H: G: S$ composition determined upon NMR (4:87:9) and the $S / G$ ratio (0.10) were also similar to that obtained upon Py-GC/MS and confirmed the extremely high content of $\mathrm{G}$ units in this lignin. The lower abundance of $\beta-O-4^{\prime}$ ether linkages and the higher content of condensed linkages, compared with the MWL from flax bast fiber, together with the high lignin content $(29.0 \%$ Klason lignin), will make flax shives even more difficult to delignify than the bast fibers.

Thioacidolysis of the MWLs from Flax Bast Fibers and Shives. The MWL from flax fibers and shives were also studied by thioacidolysis. The thioacidolysis degradation products were then subjected to a Raney nickel desulfurization, and the products obtained were analyzed by GC-MS. The chromatograms of the trimethylsilylated thioacidolysis degradation products are shown in Figure 4. The released compounds were identified according to previously reported mass spectra. ${ }^{18,19,27,30,33}$ The
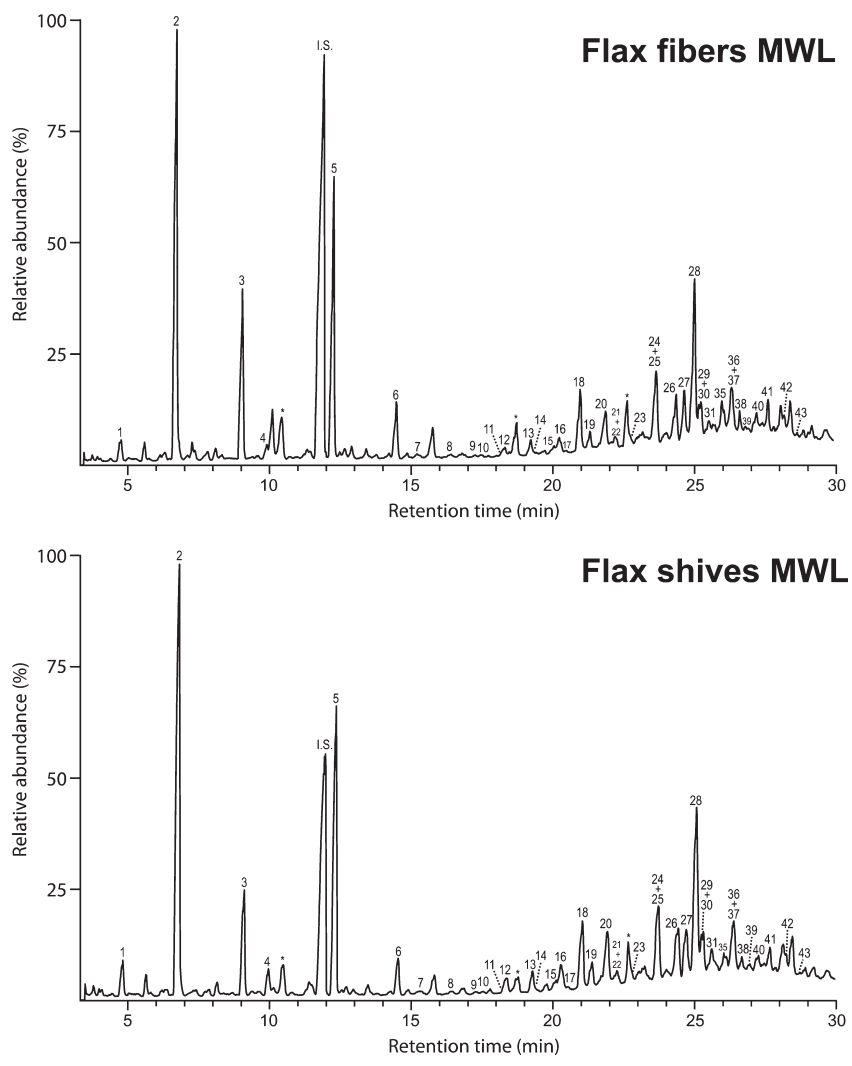

Figure 4. Chromatograms of the thioacidolysis degradation products (after Raney nickel desulfurization) released from the MWLs isolated from flax (L. usitatissimum) fibers and shives, as trimethylsilyl derivatives. The numbers refer to the compounds (monomers and dimers) listed in Table 5, and the structures are shown in Figure 5. I.S. refers to octadecane used as internal standard.

structures of the main compounds identified are shown in Figure 5, and their mass spectral data and relative molar abundances are summarized in Table 5.

The composition of the main monomers released after thioacidolysis (analyzed after Raney nickel desulfurization) showed a predominance of $\mathrm{G}$ over $\mathrm{S}$ units in the etherified lignin in both flax fibers and shives and lower amounts of $\mathrm{H}$ units, with $\mathrm{H}: \mathrm{G}: \mathrm{S}$ compositions of 5:72:23 and 7:80:13 for the MWLs from flax bast fibers and shives, respectively (Table 5). As expected, the molar S/G ratios obtained, 0.32 and 0.16 for the MWLs of flax bast fibers and shives, respectively, are higher than those estimated from Py-GC/MS and NMR, because the relative distribution of the thioacidolysis monomers reflects only the lignin units involved in alkyl-aryl ether bonds $\left(\beta-O-4^{\prime}\right.$ and $\left.\alpha-O-4^{\prime}\right)$, and, therefore, $\mathrm{S}$ units are mostly involved in alkyl-aryl ether linkages. The $S / G$ ratios obtained upon thioacidolysis agreed well with those previously reported ${ }^{13}$ and again indicated that these lignins are enriched in $G$ units, especially the flax shives. However, the important amounts of monomeric $\mathrm{H}$ units detected upon thioacidolysis in our work ( 5 and $7 \%$ of the total monomers released from the lignins of flax bast fibers and shives, respectively), which indicated that some $\mathrm{H}$ units are also forming $\beta-O-4^{\prime}$ linkages, could not be detected in previous works. ${ }^{13}$ It is interesting to note that $\beta-O-4^{\prime}$ aryl ether units involving $\mathrm{H}$ units were clearly seen in the HSQC spectra shown above. 
<smiles>[R]CCc1cc([R])c(O)c(C)c1</smiles>

$1 \mathrm{R}_{1}=\mathrm{R}_{2}=\mathrm{H}, \mathrm{R}_{3}=\mathrm{CH}_{3}$ $2 \mathrm{R}_{1}=\mathrm{OCH}_{3}, \mathrm{R}_{2}=\mathrm{H}, \mathrm{R}_{3}=\mathrm{CH}_{3}$ $3 \mathrm{R}_{1}=\mathrm{R}_{2}=\mathrm{OCH}_{3}, \mathrm{R}_{3}=\mathrm{CH}_{3}$ $4 \mathrm{R}_{1}=\mathrm{R}_{2}=\mathrm{H}, \mathrm{R}_{3}=\mathrm{CH}_{2} \mathrm{OH}$ $5 \mathrm{R}_{1}=\mathrm{OCH}_{3}, \mathrm{R}_{2}=\mathrm{H}, \mathrm{R}_{3}=\mathrm{CH}_{2} \mathrm{OH}$

$6 \mathrm{R}_{1}=\mathrm{R}_{2}=\mathrm{OCH}_{3}, \mathrm{R}_{3}=\mathrm{CH}_{2} \mathrm{OH}$<smiles>[R3]CCc1cc([R])c(O)c(-c2cc(CC[R])cc([R])c2O)c1</smiles>

$7 \mathrm{R}_{1}=\mathrm{R}_{2}=\mathrm{R}_{3}=\mathrm{R}_{4}=\mathrm{H}$

$8 \mathrm{R}_{1}=\mathrm{R}_{2}=\mathrm{R}_{3}=\mathrm{H}, \mathrm{R}_{4}=\mathrm{CH}_{3}$

$9 \mathrm{R}_{1}=\mathrm{R}_{2}=\mathrm{R}_{4}=\mathrm{H}, \mathrm{R}_{2}=\mathrm{OCH}_{3}$

$10 \mathrm{R}_{1}=\mathrm{R}_{2}=\mathrm{H}, \mathrm{R}_{3}=\mathrm{R}_{4}=\mathrm{CH}_{3}$

$11 \mathrm{R}_{1}=\mathrm{R}_{3}=\mathrm{H}, \mathrm{R}_{2}=\mathrm{OCH}_{3}, \mathrm{R}_{4}=\mathrm{CH}_{3}$

$13 \mathrm{R}_{1}=\mathrm{R}_{2}=\mathrm{OCH}_{3}, \mathrm{R}_{3}=\mathrm{R}_{4}=\mathrm{H}$

$14 \mathrm{R}_{1}=\mathrm{H}, \mathrm{R}_{2}=\mathrm{OCH}_{3}, \mathrm{R}_{3}=\mathrm{R}_{4}=\mathrm{CH}_{3}$

$15 \mathrm{R}_{1}=\mathrm{R}_{2}=\mathrm{OCH}_{3}, \mathrm{R}_{3}=\mathrm{H}, \mathrm{R}_{4}=\mathrm{CH}_{3}$

$18 \mathrm{R}_{1}=\mathrm{R}_{2}=\mathrm{OCH}_{3}, \mathrm{R}_{3}=\mathrm{R}_{4}=\mathrm{CH}_{3}$

$27 \mathrm{R}_{1}=\mathrm{R}_{2}=\mathrm{OCH}_{3}, \mathrm{R}_{3}=\mathrm{CH}_{3}, \mathrm{R}_{4}=\mathrm{CH}_{2} \mathrm{OH}$<smiles>[R]c1cc(CC([R])c2cc([R])c(O)c([R])c2)cc([R])c1O</smiles>

$12 \mathrm{R}_{1}=\mathrm{R}_{2}=\mathrm{R}_{3}=\mathrm{R}_{4}=\mathrm{R}_{5}=\mathrm{H}$

$16 \mathrm{R}_{1}=\mathrm{R}_{3}=\mathrm{R}_{4}=\mathrm{R}_{5}=\mathrm{H}, \mathrm{R}_{2}=\mathrm{OCH}_{3}$

$20 \mathrm{R}_{1}=\mathrm{R}_{3}=\mathrm{R}_{5}=\mathrm{H}, \mathrm{R}_{2}=\mathrm{R}_{4}=\mathrm{OCH}_{3}$

$26 \mathrm{R}_{1}=\mathrm{R}_{3}=\mathrm{H}, \mathrm{R}_{2}=\mathrm{R}_{4}=\mathrm{OCH}_{3}, \mathrm{R}_{5}=\mathrm{CH}_{2} \mathrm{OH}$

$31 \mathrm{R}_{1}=\mathrm{R}_{2}=\mathrm{R}_{4}=\mathrm{OCH}_{3}, \mathrm{R}_{3}=\mathrm{CH}_{2} \mathrm{OH}, \mathrm{R}_{5}=\mathrm{H}$

$39 \mathrm{R}_{1}=\mathrm{R}_{2}=\mathrm{R}_{3}=\mathrm{R}_{4}=\mathrm{OCH}_{3}, \mathrm{R}_{5}=\mathrm{CH}_{2} \mathrm{OH}$

$$
\beta-\beta^{\prime}
$$<smiles>[R]c1cc(C2c3c(cc(OC)c(O)c3[R])CC(C)C2C)cc(OC)c1O</smiles>

$29 \mathrm{R}_{1}=\mathrm{H}, \mathrm{R}_{2}=\mathrm{OCH} 3$

$34 \mathrm{R}_{1}=\mathrm{OCH}_{3}, \mathrm{R}_{2}=\mathrm{H}$

32, 35, $38 \quad \mathrm{R}_{1}=\mathrm{OCH}_{3}, \quad \mathrm{R}_{2}=\mathrm{OCH}_{3}$<smiles>[R]c1cc(CCC)cc(OC)c1Oc1c(O)cc(CCC)cc1OC</smiles>

$19 \mathrm{R}=\mathrm{H}$

$22 \mathrm{R}=\mathrm{OCH}_{3}$<smiles>[R]CCc1cc([R])c(O)c(C([R])Cc2cc([R])c(O)c([R])c2)c1</smiles>

$17 \mathrm{R}_{1}=\mathrm{R}_{2}=\mathrm{R}_{3}=\mathrm{R}_{4}=\mathrm{H}, \mathrm{R}_{5}=\mathrm{CH}_{3}$

$21 \mathrm{R}_{1}=\mathrm{R}_{3}=\mathrm{R}_{4}=\mathrm{H}, \mathrm{R}_{2}=\mathrm{OCH}_{3}, \mathrm{R}_{5}=\mathrm{CH}_{3}$

$23 \mathrm{R}_{1}=\mathrm{R}_{4}=\mathrm{R}_{5}=\mathrm{H}, \mathrm{R}_{2}=\mathrm{R}_{3}=\mathrm{OCH}_{3}$

$24 \mathrm{R}_{1}=\mathrm{R}_{3}=\mathrm{H}, \mathrm{R}_{2}=\mathrm{OCH}_{3}, \mathrm{R}_{4}=\mathrm{CH}_{2} \mathrm{OH}, \mathrm{R}_{5}=\mathrm{CH}_{3}$

$25 \mathrm{R}_{1}=\mathrm{H}, \mathrm{R}_{2}=\mathrm{R}_{3}=\mathrm{OCH}_{3}, \mathrm{R}_{4}=\mathrm{H}, \mathrm{R}_{5}=\mathrm{CH}_{3}$

$28 \mathrm{R}_{1}=\mathrm{H}, \mathrm{R}_{2}=\mathrm{R}_{3}=\mathrm{OCH}_{3}, \mathrm{R}_{4}=\mathrm{CH}_{2} \mathrm{OH}, \mathrm{R}_{5}=\mathrm{CH}_{3}$

$30 \mathrm{R}_{1}=\mathrm{OCH}_{3}, \mathrm{R}_{2}=\mathrm{R}_{3}=\mathrm{OCH}_{3}, \mathrm{R}_{4}=\mathrm{H}, \mathrm{R}_{5}=\mathrm{CH}_{3}$

$33 \mathrm{R}_{1}=\mathrm{R}_{3}=\mathrm{R}_{4}=\mathrm{H}, \mathrm{R}_{2}=\mathrm{R}_{3}=\mathrm{OCH}_{3}$

$36 \mathrm{R}_{1}=\mathrm{R}_{2}=\mathrm{R}_{3}=\mathrm{OCH}_{3}, \mathrm{R}_{4}=\mathrm{CH}_{2} \mathrm{OH}, \mathrm{R}_{5}=\mathrm{CH}_{3}$

$40 \mathrm{R}_{1}=\mathrm{R}_{4}=\mathrm{H}, \mathrm{R}_{2}=\mathrm{R}_{3}=\mathrm{OCH}_{3}, \mathrm{R}_{5}=\mathrm{CH}_{2} \mathrm{OH}$

$43 \mathrm{R}_{1}=\mathrm{R}_{2}=\mathrm{R}_{3}=\mathrm{OCH}_{3}, \mathrm{R}_{4}=\mathrm{H}, \mathrm{R}_{5}=\mathrm{CH}_{2} \mathrm{OH}$

Isochroman<smiles>[R]c1cc(C2OC(CC)c3c(cc([R])c(O)c3OC)C2C)cc(OC)c1O</smiles>

THF<smiles>COc1cc(CC2COCC2Cc2ccc(O)c(OC)c2)ccc1O</smiles>

Figure 5. Structures of monomeric and dimeric compounds obtained after thioacidolysis and Raney nickel desulfurization of the MWLs isolated from flax (L. usitatissimum) fibers and shives. The mass spectral data of the compounds (as trimethylsilyl derivatives) are listed in Table 5.

The thioacidolysis lignin monomers $(\mathrm{H}, \mathrm{G}$, and $\mathrm{S}$ ) were released in lower amounts from the MWL of flax bast fibers ( $908 \mu \mathrm{mol} / \mathrm{g}$ lignin) than from the MWL of flax shives $(1445 \mu \mathrm{mol} /$ g lignin). Similar results were also obtained after in situ thioacidolysis of the whole cell walls of flax bast fibers and shives, without previous lignin isolation, by Day et al., ${ }^{13}$ and led these authors to conclude that the lignin from flax bast fibers was more condensed than the lignin from flax shives. However, this observation contrasts with the data obtained from NMR that indicated a slightly higher proportion of
$\beta$-O-4 linkages in the lignin from flax bast fibers ( $58 \%$ of all side chains) than in the lignin from flax shives (50\% of all side chains). It is, however, possible that the purity of the MWL preparations, which were estimated by the acetyl bromide method (a spectrophotometric assay), and which was also used by Day et al..$^{13}$ to measure the lignin content of the whole cell walls, may have overestimated the lignin content, especially in the case of MWL from bast flax fibers, as has been reported to occur in herbaceous plants. ${ }^{49}$ In this sense, it appears that other moieties are present in the MWL from flax fibers, 
Table 5. Identification, Mass Spectral Fragments, and Relative Molar Abundances of the Compounds (Silylated Monomers and Dimers) Released after Thioacidolysis and Raney Nickel Desulfurization of the MWLs from Flax

(L. usitatissimum) Fibers and Shives, the Structures of Which Are Depicted in Figure 5

\begin{tabular}{|c|c|c|c|c|c|}
\hline label & compound & fragments ${ }^{a}(m / z)$ & $M_{\mathrm{w}}$ & flax fiber MWL & flax shive MWL \\
\hline \multicolumn{6}{|c|}{ monomers } \\
\hline 1 & $\mathrm{H}$ & $208,193,179$ & 208 & 3.6 & 4.8 \\
\hline 2 & G & $238,223,209,179,73$ & 238 & 49.9 & 54.5 \\
\hline 3 & S & $\underline{268}, 253,239,238,209$ & 268 & 17.8 & 10.4 \\
\hline 4 & $\mathrm{H}-\mathrm{OH}$ & $296,281,235, \underline{206}, 191,73$ & 296 & 1.4 & 2.3 \\
\hline 5 & $\mathrm{G}-\mathrm{OH}$ & $326,311,236, \underline{206}, 179$ & 326 & 22.4 & 25.0 \\
\hline 6 & $\mathrm{~S}-\mathrm{OH}$ & $356,341,240$ & 356 & 4.9 & 3.0 \\
\hline \multicolumn{3}{|c|}{ H:G:S composition from monomers } & & $5: 72: 23$ & $7: 80: 13$ \\
\hline \multicolumn{6}{|c|}{ dimers } \\
\hline 7 & $5-5^{\prime}(\mathrm{HH})$ & $386,371,357,209,179, \underline{73}$ & 386 & 1.0 & 1.0 \\
\hline 8 & $5-5^{\prime}(\mathrm{HH})$ & $400,485,371,209,147, \overline{11} 7, \underline{73}$ & 400 & 1.0 & 0.7 \\
\hline 9 & $5-5^{\prime}(\mathrm{GH})$ & $416,401,387,327,179,117, \overline{73}$ & 416 & 0.4 & 0.4 \\
\hline 10 & $5-5^{\prime}(\mathrm{HH})$ & $414,399,385,147, \underline{73}$ & 414 & 0.4 & 0.3 \\
\hline 11 & $5-5^{\prime}(\mathrm{HG})$ & $430,415,401,147, \underline{73}$ & 430 & 0.7 & 0.4 \\
\hline 12 & $\beta-1^{\prime}(\mathrm{HH})$ & $358,343, \underline{179}, 73$ & 358 & 0.5 & 0.6 \\
\hline 13 & $5-5^{\prime}(\mathrm{GG})$ & $446,431, \overline{417}, 416, \underline{73}$ & 446 & 2.9 & 3.2 \\
\hline 14 & $5-5^{\prime}(\mathrm{HG})$ & $444,429,415,147, \underline{73}$ & 444 & 0.4 & 0.4 \\
\hline 15 & $5-5^{\prime}(\mathrm{GG})$ & $460,445,431,430, \overline{73}$ & 460 & 1.1 & 1.3 \\
\hline 16 & $\beta-1^{\prime}(\mathrm{HG})$ & $388,373,209,179, \overline{73}$ & 388 & 3.5 & 4.7 \\
\hline 17 & $\beta-5^{\prime}(\mathrm{HH})$ & $400,385,221,179,73$ & 400 & 0.4 & 0.8 \\
\hline 18 & $5-5^{\prime}(\mathrm{GG})$ & $474,459,445,444,385,357, \underline{73}$ & 474 & 9.9 & 9.2 \\
\hline 19 & $4-O-5^{\prime}(\mathrm{GG})$ & $\underline{402}, 387,373,372,357,343,73$ & 402 & 2.9 & 4.0 \\
\hline 20 & $\beta-1^{\prime}(\mathrm{GG})$ & $\overline{418}, 209,179,73$ & 418 & 8.1 & 9.4 \\
\hline 21 & $\beta-5^{\prime}(\mathrm{HG})$ & $430,415,251,236,207, \underline{179}, 73$ & 430 & 0.8 & 1.1 \\
\hline 22 & $4-\mathrm{O}-5^{\prime}$ (GS) & $\underline{432}, 417,403,73$ & 432 & 0.8 & 0.6 \\
\hline 23 & $\beta-5^{\prime}(\mathrm{GG})$ & $446,431,237, \underline{209}, 179,73$ & 446 & 0.2 & 0.1 \\
\hline 24 & $\beta-5^{\prime}(\mathrm{HG}, \mathrm{OH})$ & $532,442,263,209,191, \underline{73}$ & 532 & 2.1 & 2.5 \\
\hline 25 & $\beta-5^{\prime}(\mathrm{GG})$ & $460,445,251,236, \underline{209}, 207,179,73$ & 460 & 12.6 & 11.6 \\
\hline 26 & $\beta-1^{\prime}(\mathrm{GG}, \mathrm{OH})$ & $520,505, \underline{311}, 223, \overline{209}, 179,149,73$ & 520 & 6.8 & 7.6 \\
\hline 27 & $5-5^{\prime}(\mathrm{GG}, \mathrm{OH})$ & $\underline{562}, 547,357,191,73$ & 562 & 6.3 & 6.0 \\
\hline 28 & $\beta-5^{\prime}(\mathrm{GG}, \mathrm{OH})$ & $562,472,352,263,209,191, \underline{73}$ & 562 & 19.8 & 20.2 \\
\hline 29 & $\beta-\beta^{\prime}(\mathrm{GS})$ & $502,306,269,239,209, \underline{73}$ & 502 & 0.3 & 0.4 \\
\hline 30 & $\beta-5^{\prime}(\mathrm{GS})$ & $490, \underline{239}, 209,73$ & 490 & 1.0 & 1.2 \\
\hline 31 & $\beta-1^{\prime}(\mathrm{GS}, \mathrm{OH})$ & $550,535,341, \underline{73}$ & 550 & 1.0 & 0.5 \\
\hline 32 & $\beta-\beta^{\prime}(\mathrm{SS})$ & $\underline{532}, 517,502,445,306,291,275,73$ & 532 & 0.1 & 0.2 \\
\hline 33 & $\beta-5^{\prime}(\mathrm{HG}, \mathrm{OH})$ & $\underline{532}, 209,179,147,73$ & 518 & 0.6 & 0.5 \\
\hline 34 & $\beta-\beta^{\prime}(\mathrm{GS})$ & $502,487,472,415,276, \underline{73}$ & 502 & 0.2 & 0.1 \\
\hline 35 & $\beta-\beta^{\prime}(\mathrm{SS})$ & $\underline{532}, 517,502,445,306,291,275,73$ & 532 & 1.3 & 1.1 \\
\hline 36 & $\beta-5^{\prime}(\mathrm{GS}, \mathrm{OH})$ & $592,502,472,239,209,191, \underline{73}$ & 592 & 4.1 & 3.7 \\
\hline 37 & $\beta-1^{\prime}-\alpha-O-\alpha^{\prime}(\mathrm{GG})$ & $488,473,459,279,251,209, \underline{73}$ & 488 & 2.5 & 2.3 \\
\hline 38 & $\beta-\beta^{\prime}(\mathrm{SS})$ & $\underline{532}, 517,502,445,306,291,275,73$ & 532 & 0.2 & 0.1 \\
\hline 39 & $\beta-1^{\prime}(\mathrm{SS}, \mathrm{OH})$ & $\overline{580}, 565, \underline{341}, 239,209,73$ & 580 & 1.1 & 0.5 \\
\hline 40 & $\beta-5^{\prime}(\mathrm{GG}, \mathrm{OH})$ & $548,339,223,209,179,149,73$ & 548 & 1.9 & 1.4 \\
\hline 41 & $\beta-1^{\prime}-\alpha-O-\alpha^{\prime}(\mathrm{GS})$ & $518,503,489,279,251,239,209, \underline{73}$ & 518 & 1.5 & 0.7 \\
\hline 42 & THF & $488,209,179, \underline{73}$ & 488 & 1.2 & 0.7 \\
\hline 43 & $\beta-5^{\prime}(\mathrm{GS}, \mathrm{OH})$ & $578,209,179, \overline{149}, \underline{73}$ & 578 & 0.6 & 0.4 \\
\hline \multicolumn{3}{|c|}{$\mathrm{H}: \mathrm{G}: \mathrm{S}$ composition from dimers } & & $6: 86: 8$ & $7: 86: 7$ \\
\hline
\end{tabular}

as suggested by the presence of cross-signals of cutin-like material in the aliphatic region of the HSQC spectra (not shown).
It is interesting to note that, despite the high proportion of $\mathrm{H}$ units present in the MWL from bast fibers (13\% of total lignin 
Table 6. Relative Molar Abundances of the Different Dimer Types (See Table 5 and Figure 5) Released after Thioacidolysis (and Raney Nickel Desulfurization) of the MWLs from Flax (L. usitatissimum) Fibers and Shives

\begin{tabular}{|c|c|c|c|}
\hline linkage type & units involved & flax fiber MWL & flax shive MWL \\
\hline \multirow[t]{3}{*}{$5-5^{\prime}$} & $\mathrm{HH}$ & 2.3 & 2.0 \\
\hline & HG & 1.5 & 1.2 \\
\hline & GG & 20.3 & 19.8 \\
\hline \multirow[t]{5}{*}{$\beta-1^{\prime}$} & $\mathrm{HH}$ & 0.5 & 0.6 \\
\hline & $\mathrm{HG}$ & 3.5 & 4.7 \\
\hline & GG & 17.4 & 19.3 \\
\hline & GS & 2.4 & 1.2 \\
\hline & SS & 1.1 & 0.5 \\
\hline \multirow[t]{4}{*}{$\beta-5^{\prime}$} & $\mathrm{HH}$ & 0.4 & 0.8 \\
\hline & $\mathrm{HG}$ & 3.5 & 4.1 \\
\hline & GG & 34.5 & 33.2 \\
\hline & GS & 5.7 & 5.4 \\
\hline \multirow[t]{2}{*}{$4-O-5^{\prime}$} & GG & 2.9 & 4.0 \\
\hline & GS & 0.8 & 0.6 \\
\hline \multirow[t]{2}{*}{$\beta-\beta^{\prime}$} & GS & 0.4 & 0.5 \\
\hline & SS & 1.6 & 1.4 \\
\hline THF & GG & 1.2 & 0.7 \\
\hline
\end{tabular}

units), only a minor part of them, those that form $\beta-O-4^{\prime}$ linkages, were released upon thioacidolysis of this lignin ( $5 \%$ of total thioacidolysis monomers), which indicates that $\mathrm{H}$ units in this lignin are mostly in condensed form. On the contrary, the higher proportion of $\mathrm{H}$ monomers released upon thioacidolysis of the MWL from flax shives (7\% of total thioacidolysis monomers), despite the low abundance of $\mathrm{H}$ units in this lignin (5\% of total lignin units), indicates that the $\mathrm{H}$ units in this lignin are mostly $\beta$ $O-4^{\prime}$ linked, as can be seen in the HSQC spectrum of Figure 2, where the signal from the $\mathrm{C}_{\beta}-\mathrm{H}_{\beta}$ correlations of $\beta-O-4^{\prime}$ substructures linked to an $\mathrm{H}$-lignin unit is clearly more intense in the case of the MWL from flax shives than in the MWL from flax fibers.

On the other hand, the dimers recovered after thioacidolysis can provide useful information about the different units involved in the various carbon-carbon and diaryl ether linkages, often referred to as the "condensed" bonds (including 5-5', 4-O-5', $\beta$ $1^{\prime}, \beta-5^{\prime}$, and $\beta-\beta^{\prime}$ in Table 5). ${ }^{30,31}$ The dimers identified were 5-5' (dimers 7-11, 13-15, 18, and 27), $\beta$-1' (dimers 12, 16, 20, 26, 31 , and 39), $\beta-5^{\prime}$ (dimers 17, 21, 23-25, 28, 30, 33, 36, 40, 43), $4-O-5^{\prime}$ (dimers 19 and 22), $\beta-\beta^{\prime}$ tetralin (dimers 29, 32, 34, 35, and 38), phenylisochroman (dimers 37 and 41, including $\beta-1^{\prime} /$ $\beta$-O- $\beta^{\prime}$ bonds), and tetrahydrofuran (THF) (dimer 42) types. The relative molar abundances of the different types of condensed dimers released from the MWL of flax fibers and shives are shown in Table 6. The total amounts of dimeric compounds released upon thioacidolysis of the MWL from flax bast fibers ( $555 \mu \mathrm{mol} / \mathrm{g}$ lignin) were also lower than those released from the MWL from flax shives $(991 \mu \mathrm{mol} / \mathrm{g}$ lignin $)$, probably as a result of impurities in the former, but the H:G:S composition of the total identified dimers is similar in both cases. These data, together with the low amounts of $\mathrm{H}$ monomers released from the MWL of flax bast fibers, despite the high amounts of $\mathrm{H}$ units in this lignin as said above, indicate that the $\mathrm{H}$ units present in flax bast fibers are mostly in the form of trimeric or higher (oligomeric) condensed structures. In addition, the high yields of thioacidolysis dimeric structures reveal the high condensation degree of the flax lignins.

Dimeric compounds with $\beta-5^{\prime}$ structures were the most prominent thioacidolysis dimers released from the lignins of flax fibers and shives, accounting for 44.1 and $43.5 \%$ of the total identified dimers, respectively. In both cases, the most important dimeric $\beta-5^{\prime}$ structure was formed by two $\mathrm{G}$ units, whereas $\mathrm{HH}$, $\mathrm{HG}$, and GS dimers were released in lower abundances. These data are in agreement with the 2D-NMR spectra that indicate that phenylcoumaran structures are the most important condensed structures observed in these lignins. $\beta$ - $1^{\prime}$ structures represented the second most abundant dimers and accounted for 24.9 and $26.3 \%$ of all dimeric structures in the MWL of flax bast fibers and shives, respectively. As occurs with the $\beta-5^{\prime}$ structures, the most important $\beta$-1 $1^{\prime}$ dimeric structure was formed by two $\mathrm{G}$ units, whereas other dimeric structures (HH, HG, GS, and SS) were present in lower amounts. However, these high amounts of $\beta$ - $1^{\prime}$ dimers observed upon thioacidolysis are not in agreement with the NMR data shown above, which indicated the presence of only minor amounts of spirodienones in these lignin samples $\left(3-4 \%\right.$ of all side chains involved). Dimers of $5-5^{\prime}$ structure were the third most important dimeric compounds in these lignin samples, accounting for 24.1 and $23.0 \%$ of all dimeric compounds in flax bast fibers and shives, respectively. Dimers with two G units were the most abundant, with lower amounts of $\mathrm{HH}$ and $\mathrm{HG}$ dimeric structures. Dibenzodioxocins are supposed to be the main biphenyl structures in lignin; ${ }^{44,45}$ therefore, the $5-5^{\prime}$ dimers can be considered mostly as being dibenzodioxocin degradation products, although simple biphenyl structures have also been reported in lignin. ${ }^{21}$ The rest of the dimeric compounds, such as $4-O-5^{\prime}, \beta-\beta^{\prime}$, and THF, were present in lower amounts. Among these, it is interesting to note the low proportion of $\beta-\beta^{\prime}$ dimers observed after thioacidolysis (ca. $2 \%$ of total dimeric structures) in contrast to the relatively high amounts of $\beta-\beta^{\prime}$ resinol-type structures observed in the HSQC spectra (9\% of all side chains). This fact may indicate these $\beta-\beta^{\prime}$ resinol-type structures could probably be linked with other condensed bonds $\left(\beta-5^{\prime}\right.$ or $\left.5-5^{\prime}\right)$ and, therefore, after thioacidolysis they will form trimers or higher oligomers that cannot be detected. Thioacidolysis trimeric compounds formed by $\beta-\beta^{\prime}$ tetralin dimers linked by a $4-O-5^{\prime}$ ether bond to a $\mathrm{G}$ lignin unit have been previously identified in other bast fibers, such as jute, ${ }^{18}$ and also in hardwoods ${ }^{19,50}$ and softwoods. ${ }^{51}$

In conclusion, this study indicates that the content, composition, and structure of the lignins from flax bast fibers and shives are different. However, and despite the low lignin content in flax bast fibers, the high proportions of $\mathrm{H}$ and, especially, $\mathrm{G}$ units, make the lignin of this fiber highly condensed (including over $40 \%$ carbon - carbon-linked lignin substructures) and potentially resistant to depolymerization. On the other hand, the high abundance of $\mathrm{G}$ units, the low abundance of $\beta-O-4^{\prime}$ ether linkages, and the higher content of lignin condensed substructures (nearly 50\% carbon-carbon-linked substructures) forming thioacidolysis dimers, together with the high lignin content in flax shives, make this material still more difficult to depolymerize than the bast fibers. 


\section{AUTHOR INFORMATION}

\section{Corresponding Author}

*Phone: +34 954624711. Fax: +34 954624002. E-mail: delrio@ irnase.csic.es.

\section{Funding Sources}

This study has been funded by the Spanish Project AGL200800709, CSIC Projects 200640I039 and 201040E075, and EU Projects BIORENEW (NMP2-CT-2006-026456) and LIGNODECO (KBBE-244362). J.R. thanks the Spanish CSIC for an I3P fellowship; G.M. thanks the Spanish Ministry of Education for a FPI fellowship.

\section{ACKNOWLEDGMENT}

We thank J. M. Gras and G. Artal (CELESA, Spain) for providing the flax fibers and shives and Y. Tobimatsu for performing the GPC analyses.

\section{REFERENCES}

(1) Ragauskas, A. J.; Williams, C. K.; Davison, B. H.; Britovsek, G.; Cairney, J.; Eckert, C. A.; Frederick, W. J.; Hallett, J. P.; Leak, D. J.; Liotta, C. L.; Mielenz, J. R.; Murphy, R.; Templer, R; Tschaplinski, T. The path forward for biofuels and biomaterials. Science 2006, 311, 484-489.

(2) Reddy, N.; Yang, Y. Biofibers from agriculture bioproducts for industrial applications. Trends Biotechnol. 2005, 23, 22-27.

(3) van Dam, J. E. G.; van Vilsteren, G. E. T.; Zomers, F. H. A.; Shannon, W. B.; Hamilton, I. T. Increased application of domestically produced plant fibres in textiles, pulp and paper production, and composite materials. Industrial Fiber Crops; European Commission Directorate-General XII: Brussels, Belgium, 1996.

(4) Bos, H. L.; Van Den Oever, M. J. A.; Peters, O. C.J.J. Tensile and compressive properties of flax fibres for natural fibre reinforced composites. J. Mater. Sci. 2002, 37, 1683-1692.

(5) Cox, M.; El-Shafey, E.; Pichugin, A. A.; Appleton, Q. Preparation and characterization of a carbon adsorbent from flax shive by dehydration with sulfuric acid. J. Chem. Technol. Biotechnol. 1999, 74, 1019-1029.

(6) Sain, M.; Fortier, D. Flax shives refining, chemical modification and hydrophobisation for paper production. Ind. Crops Prod. 2002, $15,1-13$.

(7) Naik, S.; Goud, V. V.; Rout, P. K.; Jacobson, K.; Dalai, A. K. Characterization of Canadian biomass for alternative renewable biofuel. Renewable Energy 2010, 35, 1624-1631.

(8) Buranov, A. U.; Mazza, G. Lignin in straw of herbaceous crops (review). Ind. Crops Prod. 2008, 28, 237-259.

(9) Love, G. D.; Snape, C. E.; Jarvis, M. C.; Morrison, I. M. Determination of phenolic structures in flax fibres by solid-state ${ }^{13} \mathrm{C}$ NMR. Phytochemistry 1993, 35, 489-491.

(10) Morrison, W. H.; Himmelsbach, D. S.; Akin, D. E.; Evans, J. D. Chemical and spectroscopic analysis of lignins in isolated flax fibers. J. Agric. Food Chem. 2003, 51, 2565-2568.

(11) del Río, J. C.; Gutiérrez, A.; Martínez, A. T. Identifying acetylated lignin units in non-wood fibers using pyrolysis-gas chromatography/mass spectrometry. Rapid Commun. Mass Spectrom. 2004, $18,1181-1185$.

(12) del Río, J. C.; Gutiérrez, A.; Rodríguez, I. M.; Ibarra, D.; Martínez, A. T. Composition of non-woody plant lignins and cinnamic acids by Py-GC/MS, Py/TMAH and FT-IR. J. Anal. Appl. Pyrolysis 2007, 79, 39-46.

(13) Day, A.; Ruel, K.; Neutelings, G.; Crônier, D.; David, H.; Hawkins, S.; Chabbert, B. Lignification in the flax stem: evidence for an unusual lignin in bast fibers. Planta 2005, 222, 234-45.

(14) Björkman, A. Studies on finely divided wood. Part I. Extraction of lignin with neutral solvents. Sven. Papperstidn. 1956, 59, 477-485.
(15) Faix, O.; Meier, D.; Fortmann, I. Thermal degradation products of wood. A collection of electron-impact (EI) mass spectra of monomeric lignin derived products. Holz Roh-Werkstoff 1990, 48, 351-354.

(16) Ralph, J.; Hatfield, R. D. Pyrolysis-GC/MS characterization of forage materials. J. Agric. Food Chem. 1991, 39, 1426-1437.

(17) del Río, J. C.; Gutiérrez, A.; Hernando, M.; Landín, P.; Romero, J.; Martínez, A. T. Determining the influence of eucalypt lignin composition in paper pulp yield using Py-GC/MS. J. Anal. Appl. Pyrol. 2005, 74, 110-115.

(18) del Río, J. C.; Rencoret, J.; Marques, G.; Li, J.; Gellerstedt, G.; Jiménez-Barbero, J.; Martínez, A. T.; Gutiérrez, A. Structural characterization of the lignin from jute (Corchorus capsularis) fibers. J. Agric. Food Chem. 2009, 57, 10271-10281.

(19) Rencoret, J.; Marques, G.; Gutiérrez, A.; Ibarra, D.; Li, J.; Gellerstedt, G.; Santos, J. I.; Jiménez-Barbero, J.; Martínez, A. T.; del Río, J. C. Structural characterization of milled wood lignin from different eucalypt species. Holzforschung 2008, 62, 514-526.

(20) Rencoret, J.; Marques, G.; Gutiérrez, A.; Nieto, L.; JiménezBarbero, J.; Martínez, A. T.; del Río, J. C. Isolation and structural characterization of the milled-wood lignin from Paulownia fortunei wood. Ind. Crops Prod. 2009, 30, 137-143.

(21) Balakshin, M. Y.; Capanema, E. A.; Goldfarb, B.; Frampton, J.; Kadla, J. F. NMR studies on Fraser fir Abies fraseri (Pursh) Poir. lignins. Holzforschung 2005, 59, 488-496.

(22) Liitiä, T. M.; Maunu, S. L.; Hortling, B.; Toikka, M.; Kilpeläinen, I. Analysis of technical lignins by two- and three-dimensional NMR spectroscopy. J. Agric. Food Chem. 2003, 51, 2136-2143.

(23) Ralph, J.; Marita, J. M.; Ralph, S. A.; Hatfield, R. D.; Lu, F.; Ede, R. M.; Peng, J.; Quideau, S.; Helm, R. F.; Grabber, J. H.; Kim, H.; Jimenez-Monteon, G.; Zhang, Y.; Jung, H.-J. G.; Landucci, L. L.; MacKay, J. J.; Sederoff, R. R.; Chapple, C.; Boudet, A. M. Solution-state NMR of lignin. In Advances in Lignocellulosics Characterization; Argyropoulos, D. S., Ed.; Tappi Press: Atlanta, GA, 1999; pp 55-108.

(24) Capanema, E. A.; Balakshin, M. Y.; Chen, C.-L.; Gratzl, J. S.; Gracz, H. Structural analysis of residual and technical lignins by ${ }^{1} \mathrm{H}-{ }^{13} \mathrm{C}$ correlation 2D NMR-spectroscopy. Holzforschung 2001, 55, 302-308.

(25) Ibarra, D.; Chávez, M. I.; Rencoret, J.; del Río, J. C.; Gutiérrez, A.; Romero, J.; Camarero, S.; Martinez, M. J.; Jiménez-Barbero, J.; Martínez, A. T. Lignin modification during Eucalyptus globulus kraft pulping followed by totally chlorine free bleaching: a two-dimensional nuclear magnetic resonance, Fourier transform infrared, and pyrolysisgas chromatography/mass spectrometry study. J. Agric. Food Chem. 2007, 55, 3477-3499.

(26) del Río, J. C.; Rencoret, J.; Marques, G.; Gutiérrez, A.; Ibarra, D.; Santos, J. I.; Jiménez-Barbero, J.; Zhang, L.; Martínez, A. T. Highly acylated (acetylated and/or $p$-coumaroylated) native lignins from diverse herbaceous plants. J. Agric. Food Chem. 2008, 56, 9525-9534.

(27) Rencoret, J.; Gutiérrez, A.; Nieto, L.; Jiménez-Barbero, J.; Faulds, C. B.; Kim, H.; Ralph, J.; Martínez, A. T.; del Río, J. C. Lignin composition and structure in young versus adult Eucalyptus globulus plants. Plant Physiol. 2011, 155, 667-682.

(28) Martínez, A. T.; Rencoret, J.; Marques, G.; Gutiérrez, A.; Ibarra, D.; Jiménez-Barbero, J.; del Río, J. C. Monolignol acylation and lignin structure in some nonwoody plants: a 2D-NMR study. Phytochemistry 2008, 69, 2831-2843.

(29) Ralph, J.; Landucci, L. L. NMR of lignins. In Lignin and Lignans; Advances in Chemistry; Heitner, C., Dimmel, D. R., Schmidt, J. A., Eds.; CRC Press (Taylor \& Francis Group): Boca Raton, FL, 2010; pp $137-234$.

(30) Lapierre, C.; Pollet, B.; Monties, B. Thioacidolysis of spruce lignin: GC-MS analysis of the main dimers recovered after Raney nickel desulphuration. Holzforschung 1991, 45, 61-68.

(31) Lapierre, C.; Pollet, B.; Rolando, C. New insights into the molecular architecture of hardwood lignins by chemical degradative methods. Res. Chem. Intermed. 1995, 21, 397-412.

(32) Rolando, C.; Monties, B.; Lapierre, C. Thioacidolysis. In Methods in Lignin Chemistry; Lin, S. Y., Dence, C. W., Eds.; SpringerVerlag: Berlin, Germany, 1992; pp 334-349. 
(33) Saito, K.; Fukushima, K. Distribution of lignin interunit bonds in the differentiating xylem of compression and normal woods of Pinus thunbergii. J. Wood Sci. 2005, 51, 246-251.

(34) Tappi Test Methods 2004-2005; Tappi Press: Norcoss, GA, 2004.

(35) Johnson, D. B.; Moore, W. E.; Zank, L. C. The spectrophotometric determination of lignin in small wood samples. Tappi 1961, 44, 793-798.

(36) Ross, K.; Mazza, G. Characteristics of lignin from flax shives as affected by extraction conditions. Int. J. Mol. Sci. 2010, 11, 4035-4050.

(37) Gutiérrez, A.; Rodríguez, I. M.; del Río, J. C. Chemical characterization of lignin and lipid fractions in kenaf bast fibers used for manufacturing high-quality papers. J. Agric. Food Chem. 2004, 52, 4764-4773.

(38) Gutiérrez, A.; Rodríguez, I. M.; del Río, J. C. Chemical characterization of lignin and lipid fractions in industrial hemp bast fibers used for manufacturing high-quality paper pulps. J. Agric. Food Chem. 2006, 54, 2138-2144.

(39) Holtman, K. H.; Chang, H. M.; Jameel, H.; Kaddla, J. F. Quantitative ${ }^{13} \mathrm{C}$ NMR characterization of milled wood lignins isolated by different milling techniques. J. Wood Chem. Technol. 2006, 26, 21-34.

(40) Baumberger, S.; Fasching, M.; Gellerstedt, G.; Gosselink, R.; Hortling, B.; Li, J.; Saake, B.; de Jong, E. Molar mass determination of lignins by size-exclusion chromatography: towards standardisation of the method. Holzforschung 2007, 61, 459-468.

(41) Marques, G.; Rencoret, J.; Gutiérrez, A.; del Río, J. C. Evaluation of the chemical composition of different non-woody plant fibers used for pulp and paper manufacturing. Open Agric. J. 2010, 4, 93-101.

(42) Tsutsumi, Y.; Kondo, R.; Sakai, K.; Imamura, H. The difference of reactivity between syringyl lignin and guaiacyl lignin in alkaline systems. Holzforschung 1995, 49, 423-428.

(43) González-Vila, F. J.; Almendros, G.; del Río, J. C.; Martín, F.; Gutiérrez, A.; Romero, J. Ease of delignification assessment of wood from different Eucalyptus species by pyrolysis (TMAH)-GC/MS and CP/MAS ${ }^{13}$ C-NMR spectroscopy. J. Anal. Appl. Pyrol. 1999, 49, 295-305.

(44) Karhunen, P.; Rummakko, P.; Sipila, J.; Brunow, G.; Kilpeläinen, I. Dibenzodioxocins - a novel type of linkage in softwood lignins. Tetrahedron Lett. 1995, 36, 169-170.

(45) Ralph, J.; Lundquist, K.; Brunow, G.; Lu, F.; Kim, H.; Schatz, P. F.; Marita, J. M.; Hatfield, R. D.; Ralph, S. A.; Christensen, J. H.; Boerjan, W. Lignins: natural polymers from oxidative coupling of 4-hydroxyphenylpropanoids. Phytochem. Rev. 2004, 3, 29-60.

(46) Kukkola, E.; Koutaniemi, S.; Pöllänen, E.; Gustafsson, M.; Karhunen, P.; Lundell, T. K.; Saranpää, P.; Kilpeläinen, I.; Teeri, T. H.; Fagerstedt, K. V. The dibenzodioxocin lignin substructure is abundant in the inner part of the secondary wall in Norway spruce and silver birch xylem. Planta 2004, 218, 497-500.

(47) Galkin, S.; Ammalahti, E.; Kilpeläinen, I.; Brunow, G.; Hatakka, A. Characterisation of milled wood lignin from reed canary grass (Phalaris arundinacea). Holzforschung 1997, 51, 130-134.

(48) Gierer, J. Chemistry of delignification. Part I: General concept and reactions during pulping. Wood Sci. Technol. 1985, 19, 289-312.

(49) Hatfield, R. D.; Grabber, J.; Ralph, J.; Brei, K. Using the acetyl bromide assay to determine lignin concentrations in herbaceous plants: some cautionary notes. J. Agric. Food Chem. 1999, 47, 628-632.

(50) Önnerud, H.; Gellerstedt, G. Inhomogeneities in the chemical structure of hardwood lignins. Holzforschung 2003, 57, 255-265.

(51) Önnerud, H. Lignin structures in normal and compression wood. Evaluation by thioacidolysis using ethanethiol and methanethiol. Holzforschung 2003, 57, 377-384. 